rev. hist. (São Paulo), n. 171, p. 383-419, jul.-dez., 2014 http://dx.doi.org/10.11606/issn.2316-9141.rh.2014.89017

\section{A DINÂMICA DAS RELAÇÕES NO NORTE DE MOÇAMBIQUE NO FINAL DO SÉCULO XIX E INÍCIO DO SÉCULO XX}

\section{Regiane Augusto de Mattos*}

Pontifícia Universidade Católica do Rio de Janeiro

\title{
Resumo
}

$\mathrm{O}$ artigo tem por objetivo apresentar os principais fatores desencadeadores e as formas de mobilização dos agentes envolvidos na "coligação de resistência" organizada, no final do século XIX, por chefes de Angoche, Sangage, Sancul, Quitangonha e dos grupos macua-imbamela e namarrais, às interferências da política colonialista portuguesa no norte de Moçambique, dando destaque para as dimensões das relações entre os diversos agentes históricos na região.

\section{Palavras-chave}

Moçambique - conexões históricas - mecanismos coloniais.

* Doutora em História pelo Programa de Pós-Graduação em História Social do Departamento de História da Faculdade de Filosofia, Letras e Ciências Humanas da Universidade de São Paulo e docente do Departamento de História do Centro de Ciências Sociais. 
rev. hist. (São Paulo), n. 171, p. 383-419, jul.-dez., 2014 http://dx.doi.org/10.11606/issn.2316-9141.rh.2014.89017
Regiane Augusto de Mattos

A dinâmica das relações no norte de Moçambique no final do século XIX e início do século XX

\title{
THE DYNAMICS
}

OF RELATIONSHIPS

IN NORTHERN

MOZAMBIQUE

AT THE END OF

THE NINETEENTH

CENTURY AND

AT THE EARLY

TWENTIETH CENTURY

Rua Marquês de São Vicente, 225

Edifício da Amizade/Ala Cardeal Frings - sala F512

22453-900 - Rio de Janeiro - Rio de Janeiro

E-mail: regianemattos@puc-rio.br

\section{Regiane Augusto de Mattos}

Pontifícia Universidade Católica do Rio de Janeiro

\begin{abstract}
The article has as objective to present the main triggering factors and ways of mobilizing agents of the "coalition resistance" organized at the end of the nineteenth century, by the leaderships of Angoche, Sangage, Sancul, Quitangonha and the groups macua-imbamela and namarrais, to the interference of the Portuguese colonialist policy in Northern Mozambique, giving prominence to the dimensions of the relations between the various historical actors in the region.
\end{abstract}

\section{Keywords}

Mozambique - historical connections - colonial mechanisms. 
rev. hist. (São Paulo), n. 171, p. 383-419, jul.-dez., 2014 http://dx.doi.org/10.11606/issn.2316-9141.rh.2014.89017
Regiane Augusto de Mattos

A dinâmica das relações no norte de Moçambique no final do século XIX e início do século XX

No final do século XIX, sultões e chefes dos estabelecimentos islâmicos da costa como Angoche, Sangage, Sancul, Quitangonha, e das sociedades do interior como os grupos chamados macua-imbamela e namarrais organizaram uma série de ações, como o intercâmbio de armas, munições e guerreiros e ataques simultâneos aos postos administrativos e militares portugueses, em resposta às intervenções do governo português no norte do atual Moçambique. ${ }^{1}$ Analisar os principais fatores desencadeadores dessas ações e as formas de mobilização dos agentes envolvidos é o principal objetivo deste artigo.

No norte de Moçambique era possível encontrar uma gama variada de grupos sociais como goeses, em sua maioria cristãos; baneanes, que eram comerciantes hindus originários sobretudo de Guzarate; e mouros, que poderiam ser indianos ou omanitas, ambos muçulmanos. ${ }^{2}$ Não se pode deixar de observar igualmente a presença de portugueses recém-chegados ou estabelecidos há gerações, ingleses e franceses, incluindo mercadores e representantes dos referidos governos.

Nota-se ainda que as chefias das sociedades do litoral, sobretudo de Angoche, mantinham relações muito próximas com as elites muçulmanas de Zanzibar e das ilhas Comores e Madagascar. O contato com essas áreas do oceano Índico fora instituído havia muito tempo, tendo um caráter econômico, mas envolvendo também um forte aspecto religioso, marcado pela presença do Islã de vertente sunita. Além de fazerem parte da rede comercial e cultural do oceano Índico, os sultões de Angoche estabeleceram relações com os grupos macuas ao criar laços de lealdade com os seus chefes a partir da doação de terras, de vínculos de parentesco e da religião, ao contribuírem para a disseminação do Islã na região. ${ }^{3}$

É preciso ressaltar que a chamada "coligação de resistência", termo que aparece frequentemente nas fontes primárias para denominar a associação entre os principais representantes políticos da região que promoveram as

1 As sociedades citadas estavam localizadas no território que hoje compõe parte da província de Nampula.

2 O termo baneane é derivado, muito provavelmente, da palavra vãniyãn, que, em língua guzarate, significa comerciante. ZAMPARONI, Valdemir. Monhés, baneanes, chinas e afro-maometanos. Colonialismo e racismo em Lourenço Marques, Moçambique, 1890-1940. Lusotopie. Paris: Ed. Karthala, 2000, p. 191-222.

3 BONATE, Liazzat. From Shirazi into Monhé: Angoche and the mainland in the context of the nineteenth century slave trade of northern Mozambique. In: ZIMBA, B.; ALPERS, E.; IASAACMAN, A. Slave route and oral tradition in Southeastern Africa. Maputo, Moçambique: Filsom Entertainment Ltda., 2005, p. 195-218. 
rev. hist. (São Paulo), n. 171, p. 383-419, jul.-dez., 2014 http://dx.doi.org/10.11606/issn.2316-9141.rh.2014.89017
Regiane Augusto de Mattos

A dinâmica das relações no norte de Moçambique no final do século XIX e início do século XX

ações contra o governo português no final do século XIX, constituiu o ponto de partida para a problematização das várias dimensões das relações estabelecidas entre esses diversos agentes históricos na região. ${ }^{4}$

Para tanto, foi utilizado um conjunto diversificado de fontes primárias, que inclui correspondências, ofícios, relatórios, relatos de viagem e memórias, consultados em diferentes arquivos e bibliotecas de São Paulo, do Rio de Janeiro, de Lisboa, de Paris e de Maputo. Vale ressaltar que, além das fontes produzidas por europeus e, em maior número, por portugueses, analisei as correspondências escritas por sultões e chefes do norte de Moçambique, preservadas no Arquivo Histórico de Moçambique. ${ }^{5}$ Essa documentação é extremamente rica, pois guarda proximidade com relação aos fatos uma vez que foi produzida no momento dos acontecimentos e trata de assuntos ligados ao cotidiano das relações entre os sultões e chefes do norte de Moçambique e as autoridades portuguesas, permitindo uma aproximação maior no que se refere às questões colocadas por esses atores.

\section{A "coligação" e o conceito de resistência na historiografia}

Existem ainda poucos trabalhos historiográficos que versam sobre a história das sociedades do norte de Moçambique e, mais especificamente, sobre a formação da "coligação de resistência" no final do século XIX. ${ }^{6}$ De

\footnotetext{
4 Embora o termo tenha sido cunhado pela documentação primária portuguesa e, portanto, passível de ser questionado, foi possível observar na pesquisa vários indícios da articulação de algumas ações, realizadas de maneira combinada, e também ações individuais, mas que revelavam troca de apoio entre os diferentes grupos e agentes sociais. Estes indícios são mais aprofundados na minha tese de doutorado que originou este artigo. MATTOS, Regiane Augusto de. As dimensões da resistência em Angoche: da expansão política do sultanato à política colonialista portuguesa no norte de Moçambique (1842-1910). Tese de doutorado em História Social, Faculdade de Filosofia, Letras e Ciências Humanas, Universidade de São Paulo. São Paulo, 2012.

5 Essas correspondências foram escritas em língua suaíli e com caracteres árabes e, em sua maioria, são acompanhadas da respectiva tradução realizada por um tradutor ligado ao governo português ("língua do Estado"). Ressalte-se que, para este trabalho, tive o cuidado de confirmar as referidas traduções analisadas.

6 NEWITT, Malyn. The early history of the sultanate of Angoche. The Journal of African History, v. 13, $\mathrm{n}^{\circ}$ 3, 1972, p. 397-406, Idem. Angoche, the slave trade and the portuguese.The Journal of African History, v. 13, no 4, 1972, p. 659-672. PÉLISSIER, René. História de Moçambique. Formação e oposição (1854-1918), v. 1. Lisboa: Editorial Estampa, 1987. ROCHA, Aurélio. O caso dos suá́lis, 18501913. REUNIÃO INTERNACIONAL DE HISTÓRIA DE ÁFRICA: RELAÇÃO EUROPA-ÁFRICA NO $3^{\circ}$ QUARTEL DO SÉCULO XIX. Anais. Lisboa: Centro de Estudos de História e Cartografia Antiga, Instituto de Investigação Cientifica e Tropical, 1989.
} 
rev. hist. (São Paulo), n. 171, p. 383-419, jul.-dez., 2014 http://dx.doi.org/10.11606/issn.2316-9141.rh.2014.89017
Regiane Augusto de Mattos

A dinâmica das relações no norte de Moçambique no final do século XIX e início do século XX

acordo com essa historiografia, a "coligação" tinha como principal objetivo a continuidade dos privilégios obtidos por meio do tráfico de escravos. Esta conclusão pode ser explicada pelo fato das referidas pesquisas se fundamentarem num conjunto de fontes documentais produzidas por portugueses e ingleses, a maioria escrita e publicada num contexto posterior aos acontecimentos, não observando o fato de que seus autores estavam comprometidos, em algum nível, fosse cobrando ou sendo cobrado, com a proibição do tráfico de escravos, e, por essa razão, destacavam essa questão nos seus registros, insistindo na intensa relação das chefias locais com esse comércio.

Vale destacar a tese de doutorado de Nancy Hafkin, Trade, society and politics in northern Mozambique, c. 1753-1913, que é um dos poucos trabalhos acadêmicos de maior fôlego sobre o norte de Moçambique. A autora aborda a origem dos estabelecimentos islâmicos da costa de Moçambique, como o sultanato de Angoche e os xecados de Sangage, Sancul e Quitangonha, descrevendo a sua expansão econômica entre o final do século XVIII e a segunda metade do século XIX, ligada intrinsecamente ao comércio de escravos, e como se configurou a relação com o governo português durante esse período. Também observa que as relações entre as elites suaílis da costa e os chefes das sociedades matrilineares macuas do interior ocorreram em torno do comércio de escravos e da expansão do Islã. A autora ressalta a perda do monopólio do comércio de escravos exercido pelo sultanato de Angoche como fator preponderante para a organização da "coligação".7

A obra mais recente sobre o sultanato de Angoche é a escrita por Liazzat Bonate, em The ascendance of Angoche: politics of kinship and territory in northern Mozambique, ${ }^{8}$ na qual analisa como o sultanato de Angoche expandiu sua influência e se tornou o maior poder político na região norte de Moçambique no século XIX.

Bonate traz uma grande contribuição ao apresentar a história do sultanato de Angoche direcionando o foco de análise para a "dinâmica das relações políticas internas africanas", destacando que os líderes de Angoche não "dirigiam seus interesses apenas para o mundo suaíli", nem promoviam "estratégias políticas somente de caráter predatório" em relação aos povos do

\footnotetext{
HAFKIN, Nancy. Trade, society and politics in northern Mozambique, c. 1753-1913. Ph. D. dissertation, Boston University Graduate School, Boston, 1973, p. 400.

8 BONATE, Liazzat J. K., op. cit., 2005. Vale destacar igualmente a sua tese de doutorado: BONATE, Liazzat J. K. Traditions and transitions. Islam and chiefship in northern Mozambique, ca. 1850-1974. Tese de doutorado, University of Cape Town, 2007.
} 
rev. hist. (São Paulo), n. 171, p. 383-419, jul.-dez., 2014 http://dx.doi.org/10.11606/issn.2316-9141.rh.2014.89017
Regiane Augusto de Mattos

A dinâmica das relações no norte de Mocambique no final do século XIX e início do século XX

interior, como medidas destinadas à escravização da população. Eles faziam uso de uma política de parentesco e de distribuição de terras que criava laços entre os chefes do interior e o sultão de Angoche que, por sua vez, favorecia o controle do comércio, sobretudo de escravos. Para a autora, a prioridade política de Angoche não era a resistência à dominação portuguesa e, sim, a expansão de sua influência política, sobretudo por meio do comércio de escravos. Dessa maneira, Bonate afirma, como os outros autores, que o comércio de escravos era o objetivo central do sultanato.?

Entretanto, ao isolar a atuação do sultanato de Angoche, abordando apenas suas estratégias políticas voltadas para as sociedades do interior no norte de Moçambique, Bonate deixa de observar a complexa dinâmica das relações entre os diferentes agentes históricos (não somente o governo português) presentes na região e o quanto esta dinâmica podia ser influente, muitas vezes direcionando essas mesmas relações internas.

Nota-se, na maior parte dos referidos trabalhos, uma tendência à comparação entre os objetivos da "coligação" organizada no norte de Moçambique no final do século XIX e os ideais dos movimentos nacionalistas do século XX, em particular os de libertação, unidade nacional e transformação social. Essa comparação foi proposta por Terence Ranger para analisar as resistências de um modo geral. Ele destaca a possibilidade de que "elementos modernos" dos nacionalismos africanos sejam encontrados em alguns casos de "resistências primárias" (organizadas contra a ocupação e a administração colonial). ${ }^{10}$

Os trabalhos que utilizaram esse tipo de abordagem, sobretudo na década de 1960, são resultado, em grande medida, da influência das lutas de libertação na África ocorridas nessa época e surgem em resposta à literatura anterior de caráter eurocêntrico, tendo como objetivo mostrar a capacidade de união e de resistência das diferentes sociedades.

Nesse sentido, o trabalho de Allen e Barbara Isaacman - A tradição da resistência em Moçambique - é emblemático." A "rebelião de Barué", ocorrida em 1917 no vale do Zambeze e considerada por estes autores como uma "resistência primária expansiva", pode ser comparada em muitos aspectos à "coligação de resistência" no norte de Moçambique formada no final do

\footnotetext{
9 Ibidem, p. 3-5.

${ }^{10}$ RANGER, Terence O. Connexions between primary resistance movements and modern mass nationalism in East and Central África. The Journal of African History, Cambridge University Press, IX, 3, 1968, p. 437-453.

${ }^{11}$ ISAACMAN, Allen \& ISAACMAN, Barbara. A tradição da resistência em Moçambique, o vale do Zambeze, 1850-1921. Porto: Edições Afrontamento, 1976, p. 272-321.
} 
rev. hist. (São Paulo), n. 171, p. 383-419, jul.-dez., 2014 http://dx.doi.org/10.11606/issn.2316-9141.rh.2014.89017
Regiane Augusto de Mattos

A dinâmica das relações no norte de Moçambique no final do século XIX e início do século XX

século XIX. Características como a escala, a articulação entre diferentes sociedades em termos de ação, liderança e objetivos comuns, planejamento de ações e comunicação entre os envolvidos podem ser observadas em ambas. Mas outros elementos que a aproximariam dos ideais nacionalistas, como a consciência de uma "africanidade" ou a intenção de libertação e transformação social, neste caso, são dificilmente possíveis de serem reconhecidas.

Nancy Hafkin argumenta que, no caso da "coligação de resistência" no norte de Moçambique, não é possível fazer uma conexão com o "moderno nacionalismo de massa" em Moçambique, pois não houve uma guerra no sentido da libertação. Para esta autora, se há alguma indicação de um senso de nacionalismo africano nessas revoltas, esta estaria no fato de considerarmos o nacionalismo como oposição ao colonialismo. Além disso, a resistência no norte de Moçambique foi reacionária, pois não estava voltada para a transformação social. ${ }^{12}$

Para Aurélio Rocha, embora a resistência tenha assumido um caráter anticolonial, "não visava qualquer tipo de libertação e corria até mesmo no sentido contrário ao do nacionalismo". Sobretudo, objetivava a "manutenção das bases do poder oligárquico" e o modo de produção baseado na escravatura. Não pretendia a transformação social, mas a preservação da exploração. ${ }^{13}$

Esse exercício de tentar encontrar elementos característicos dos movimentos nacionalistas nas chamadas resistências primárias é muito delicado, pois se corre o risco de incorrer em anacronismos pela sugestão de que os membros das "resistências primárias" eram movidos por ideias que talvez não tivessem ou que as circunstâncias históricas não permitissem que tivessem, como, por exemplo, uma consciência nacional ou uma intenção de libertação social. ${ }^{14}$

A procura sem sucesso desses elementos pode ter provocado, por parte da historiografia, uma simplificação da análise dos seus fatores desencadeadores e das formas de mobilização das diferentes sociedades no caso do norte de Moçambique, não se considerando a complexa dinâmica das relações entre os diferentes agentes sociais.

${ }^{12}$ HAFKIN, Nancy, op. cit., p. 400.

13 ROCHA, Aurélio, op. cit., p. 606-607.

${ }^{14}$ ELLIS, Steven. La conquista colonial en el centro de Madagascar: Quien resistió a qué? In: ABBINK, Jon; BRUIJN, Mirjam; WALRAVEN, Klass van (eds.). A propósito de resistir. Repensar la insurgencia en África. Barcelona: Oozebap, 2008, p. 111. 
rev. hist. (São Paulo), n. 171, p. 383-419, jul.-dez., 2014 http://dx.doi.org/10.11606/issn.2316-9141.rh.2014.89017
Regiane Augusto de Mattos

A dinâmica das relações no norte de Mocambique no final do século XIX e iníio do século XX

Uma nova historiografia sobre resistências surgiu no final da década de 1970, promovendo a crítica sobre o caráter elitista das pesquisas anteriores e os historiadores que retrataram as ações dos africanos de maneira dualista reduzindo-as a resistência versus acomodação. ${ }^{15}$ Nessa corrente historiográfica também se inseriram Allen e Barbara Isaacman, ao destacarem a tendência nos estudos africanos em abordar a resistência como a reação mais natural às investidas imperialistas, quando esta era apenas uma das opções existentes. Acrescentaram que estes estudos, ao colocarem o foco da atenção nas ações das elites africanas, não conseguiram reconhecer as ações de camponeses, escravos e comerciantes. ${ }^{16}$

Estes novos estudos dos finais da década de 1970 retrataram as lutas dos trabalhadores agrícolas durante o período colonial como resistências protonacionalistas, ampliando o uso do conceito de resistência ao incluir qualquer tipo de ação contrária ao capitalismo e ao colonialismo, como roubos, deserções, fugas, dissimulação e sabotagem, o que se convencionou denominar de protesto social. ${ }^{17}$

Mais recentemente, Frederick Cooper fez uma crítica ao uso do conceito de resistência no artigo Conflito e conexão: repensando a história colonial da África. Para este historiador o conceito de resistência em geral não é problemático quando se trata das ações desafiadoras da administração colonial, mais especificamente da construção dos argumentos para a liberação dos conflitos entre os exércitos africanos e coloniais e das desobediências e fugas individuais. Mas há uma tendência a ampliar o uso do termo, sem deixar claro o alvo da resistência e, no caso do alvo ser o colonialismo, sem destrinchar as suas implicações, expandindo-as a ponto de não enxergar outros objetivos dos agentes envolvidos. Cooper afirma que, devido ao caráter dicotômico (colonizado versus colonizador) que esse termo pode carregar, "por mais significativa que a resistência possa ser, a resistência é um conceito que pode estreitar a nossa compreensão da história da África, ao invés de expandi-la".18

\footnotetext{
${ }^{15}$ ABBINK, Jon $\mathcal{E}$ WALRAVEN, Klass van. Repensar la resistencia en la historia de África. In: ABBINK, Jon; BRUIJN, Mirjam; WALRAVEN, Klass van (eds.), op. cit., p. 16.

${ }^{16}$ ISAACMAN, Allen $\mathcal{E}$ ISAACMAN, Barbara. Resistance and collaboration in southern and central Africa, c. 1850-1920. The International Journal of African Historical Studies, vol. 10, n 1, 1977, p. 61.

${ }^{17}$ ISAACMAN, Allen. Cotton is the mother of poverty: peasant resistance to forced cotton production in Mozambique, 1938-1961. International Journal of African Historical Studies, nº 13, 1980, p. 614. Com relação ao tema, mas especificamente tratando de regiões da Ásia ver: SCOTT, James. Weapons of the weak: everyday forms of peasant resistance. New Haven: Yale University Press, 1985.

${ }^{18}$ COOPER, Frederick. Conflito e conexão: repensando a história colonial da África. Revista Anos 90, Porto Alegre, v. 15, nº 27, jul. 2008, p. 28.
} 
rev. hist. (São Paulo), n. 171, p. 383-419, jul.-dez., 2014 http://dx.doi.org/10.11606/issn.2316-9141.rh.2014.89017
Regiane Augusto de Mattos

A dinâmica das relações no norte de Moçambique no final do século XIX e início do século XX

Neste sentido, privilegiei neste trabalho uma abordagem mais matizada da chamada "coligação de resistência" no norte de Moçambique, ressaltando mais as dinâmicas das relações entre os diferentes agentes históricos presentes na região, dando relevo aos diversos fatores desencadeadores e às formas de mobilização dos diferentes agentes sociais envolvidos nas ações contrárias às tentativas de intervenção do governo português na região.

\section{Formas de mobilização das diferentes sociedades}

É possível perceber que, ao longo do século XIX até o início do século XX, os chamados suaílis de Angoche, de Sancul, de Sangage e de Quitangonha, e os macuas do interior do norte de Moçambique, como os imbamelas e os namarrais, estavam integrados em espaços amplos, estruturados a partir de fatores culturais, econômicos e/ou políticos.

Analisar as sociedades do norte de Moçambique a partir da integração nesses "espaços" ajudou-me a entender a "coligação de resistência" como o resultado de um complexo de interconexões, cuja noção pressupõe a existência de vários elementos e a interação de diferentes agentes que estabelecem relações em diversos níveis: cultural, político e/ou econômico. Neste sentido, este trabalho é tributário do conceito de conexões (branchements) elaborado por Jean-Loup Amselle. ${ }^{19}$ Por meio da metáfora de uma comunicação eletrônica, em que vários fios se conectam em diferentes direções, Amselle acredita que esse conceito tende a desconstruir as ideias de limite e de fronteira das culturas, não no sentido de mistura ou de pureza, mas ressaltando as conexões possíveis entre elas.

No caso do sultanato de Angoche, fica evidente a sua importância como espaço de troca comercial, política e religiosa, integrante das redes internacionais, envolvendo não apenas as sociedades do interior do continente (macuas-imbamelas e namarrais), mas também aquelas localizadas no oceano Índico (Zanzibar, Comores, Madagascar), na medida em que era responsável pelo comércio de longa distância e por laços de lealdade estabelecidos por meio de vínculos de parentesco e de doação de terras com essas sociedades.

\footnotetext{
${ }_{19}$ AMSELLE, Jean-Loup. Branchements. Anthropologie de l'universalité des cultures. Paris: Flammarion, 2001.
} 
rev. hist. (São Paulo), n. 171, p. 383-419, jul.-dez., 2014 http://dx.doi.org/10.11606/issn.2316-9141.rh.2014.89017
Regiane Augusto de Mattos

A dinâmica das relações no norte de Moçambique no final do século XIX e início do século XX

\subsection{Laços de parentesco e doação de terras}

De acordo com a pesquisadora Liazzat Bonate, além de se integrar à rede comercial e cultural do oceano Índico, o sultanato de Angoche também dirigiu seus interesses para o, e promoveu estratégias políticas (não apenas visando o tráfico de escravos) no, interior do continente. Os líderes de Angoche mantiveram contatos comerciais e fizeram uso de uma política de parentesco em relação às sociedades localizadas desde o interior até a costa africana com elas criando laços de lealdade. ${ }^{20}$

Dessa maneira, defendo que a relação política e cultural construída entre o sultanato de Angoche e os povos do interior do continente constitui uma dimensão importante a ser considerada quando se trata de entender as ações em contraposição às investidas portuguesas na região.

Notam-se, por parte do sultanato de Angoche, tentativas de fomentar alianças entre as diferentes sociedades presentes nessa região, estabelecidas, muitas vezes, por meio de laços de parentesco, por doação de terras e pelo comércio. ${ }^{21}$ A relação, por exemplo, entre o sultanato de Angoche e a sociedade macua-imbamela foi marcada por uma política de doação de terras. Os imbamelas estavam divididos entre á-nélla e á-iadje. Ao longo do século XIX, esses dois grupos estabeleceram uma relação conflituosa. O governo português promoveu várias alianças com os á-nella. Por sua vez, os á-iadje aproximaram-se do sultanato de Angoche. Há indícios de que a relação de lealdade entre os á-iadje do chefe Guarnéa-muno e os chefes de Angoche teve início a partir da doação de terras. ${ }^{22}$

\footnotetext{
${ }^{20}$ BONATE, Liazzat J. K., op. cit., 2005, p. 115-143. BONATE, Liazzat J. K, op. cit., 2007, p. 7.

${ }^{21}$ Em 1867, o governador interino de Angoche, José Joaquim Muniz Cabral, escreveu ao secretário do governo geral da província de Moçambique, Alexandre Balduino Soares Tavares de Mendonça, relatando que alguns "monhés" que estavam no M'luli tinham ido para a Murrua levando escravos e armas com o objetivo de tratar como Mussa Quanto, sultão de Angoche, seria "introduzido" na região. Acrescenta que arranjaram em M'luli o seu casamento com uma mulher parente de um "monhé" chamado Canana. AHU, Semu, DGU. Correspondência dos governadores, Moçambique, 31 de julho de 1867, caixa 37, capilha 1, documento 65. Vale dizer que, no interior, os chefes eram chamados de muno ou mwené, enquanto no litoral levavam a designação de xeque ou sultão, não obstante estes se considerassem também muyini ou monhé (este último termo é encontrado especialmente na documentação portuguesa). O mwené (muno, muyini, monhé) era o chefe eleito pela linhagem que primeiro chegou ao território, considerado o dono ou senhor da terra. LUPI, Eduardo do Couto. Angoche. Breve memória sobre uma das capitanias-mores do distrito de Moçambique. Lisboa: Typographia do Annuario Commercial, 1907, p. 171.

${ }^{22}$ AMORIM, Pedro Massano de. Relatório sobre a ocupação de Angoche; operações de campanha e mais serviços realizados. [Lourenço Marques]: Imprensa Nacional, 1911, p. 145-174, 202-206. BONATE, Liazzat J. K., op. cit., 2007, p. 46.
} 
rev. hist. (São Paulo), n. 171, p. 383-419, jul.-dez., 2014 http://dx.doi.org/10.11606/issn.2316-9141.rh.2014.89017
Regiane Augusto de Mattos

A dinâmica das relações no norte de Moçambique no final do século XIX e ińício do século XX

Em meados do século XVIII, os imbamelas dirigiram-se à região de Angoche e se fixaram no curso médio do rio M'luli, cada vez mais tentando se aproximar do litoral com o objetivo de explorar o comércio costeiro. Nos últimos anos do século XVIII, o sultanato de Angoche negociou com os imbamelas as terras que ocupariam ao longo do M'luli, advertindo-os para que não invadissem a área reservada a cada um dos grupos. Todavia, no século XIX, foi consentido que os á-nélla ocupassem também as terras de Macogone e que os á-iadje descessem pelo vale do M'luli, cujas terras eram mais férteis do que a dos á-nélla. ${ }^{23}$

O sultanato de Angoche, ao autorizar que Guarnéa-muno ocupasse terras mais próximas aolitoral,concedeu-lhevantagens econômicas epolíticas advindas do controle do comércio costeiro e, com isso, contribuiu para o seu fortalecimento, garantindo sua autonomia em relação ao chefe Morla-muno dos á-nélla.

Pedro Massano de Amorim, militar português e governador do distrito de Moçambique, revela que Morla-muno tinha vários "dependentes" na região entre Lona e Larde, a Matadane e Mocogone e ao sul do M'luli e que, até meados do século XIX, Guarnéa-muno estava sob sua dependência, ${ }^{24}$ razão pela qual Morla-muno não aceitava a interferência política de Angoche, quando da sua expansão, travando várias guerras contra o sultanato, pois, além de ter interesse nas terras do sultanato próximas ao litoral, o próprio sultão de Angoche havia privilegiado um de seus dependentes, permitindo a ocupação daqueles territórios.

Por sua vez, a aliança luso-imbamela durou quase toda a segunda metade do século XIX. Porém, no final da década de 1880, algumas medidas do governo português provocaram descontentamentos. Em 1887, um novo chefe Morla-muno, eleito em meio aos combates entre os a-nélla e os a-iadje, procurou o governador do Parapato, ${ }^{25}$ localidade mais tarde denominada Antonio Enes, reclamando o envio de armas e pólvora como recompensa pelos serviços prestados ao governo pelo seu antecessor. O governador negou vários pedidos de auxílio ao Morla-muno, alegando não querer mais contribuir para essa guerra. No início do século XX, a aliança foi rompida dando início aos conflitos armados entre o governo português e os a-nélla.

\footnotetext{
${ }^{23}$ Idem, ibidem.

${ }^{24}$ AMORIM, Pedro Massano de, op. cit., 1911, p. 47-48.

${ }^{25}$ Localidade do continente em frente à ilha de Angoche, onde o governo português havia construído um posto administrativo.
} 
rev. hist. (São Paulo), n. 171, p. 383-419, jul.-dez., 2014 http://dx.doi.org/10.11606/issn.2316-9141.rh.2014.89017
Regiane Augusto de Mattos

A dinâmica das relações no norte de Moçambique no final do século XIX e início do século XX

O sultanato de Angoche também estabeleceu relações de lealdade a partir da doação de terras com as comunidades localizadas no território denominado M'lay e seus arredores (Selége, M'zêa e Morrua), próximos à vila de Antonio Enes. Quando algumas populações macuas do interior iniciaram um movimento migratório em direção ao litoral, essas terras estavam despovoadas por causa das razias realizadas para capturar pessoas feitas escravas. Para impedir que os migrantes chegassem aos principais portos de Kinga, Sangage e Parapato e concorressem ao controle do comércio costeiro, o sultanato de Angoche resolveu estabelecer uma barreira, deslocando aquelas comunidades do vale do rio M'lay (mais ao sul) para essa região. De acordo com Eduardo Lupi, nessa época, algumas comunidades do M'lay travavam uma disputa no território vizinho de Marrovone, devido à morte de um dos seus chefes (Marrussa-muno) por gente daquela sociedade. Por essa razão, e por serem as novas terras melhor localizadas, a população de M'lay acabou construindo laços de lealdade com o sultão de Angoche. Como resultado dessas relações, o sultanato de Angoche recebeu apoio dessas comunidades diante das interferências do governo português. Há indícios de que, já em 1861, o sultão Mussa-Quanto e os "grandes de Angoche" foram ajudados pela gente de M'lay, refugiando-se ali após a ocupação da ilha de Angoche pelos soldados do prazeiro João Bonifácio. ${ }^{26}$

Dessa maneira, as redes de lealdade construídas a partir da doação de terras e de laços de parentesco com sociedades do interior propiciaram a expansão política do sultanato de Angoche. Quando acionadas, foram essas relações de lealdade, reforçadas, sobretudo na segunda metade do século XIX, que favoreceram a mobilização das sociedades.

\subsection{Intercâmbios comerciais e expansão do Islã}

As sociedades do litoral, sobretudo o sultanato de Angoche, mantinham conexões com Zanzibar e as ilhas Comores e Madagascar relacionadas à expansão do Islã e à educação islâmica com um intercâmbio de pessoas e sabe-

\footnotetext{
${ }^{26}$ LUPI, Eduardo do Couto, op. cit., 1907, p. 173-175. CAPELA, José. A República militar da Maganja da Costa (1862-1898). Maputo: Arquivo Histórico de Moçambique,1988.
} 
rev. hist. (São Paulo), n. 171, p. 383-419, jul.-dez., 2014 http://dx.doi.org/10.11606/issn.2316-9141.rh.2014.89017
Regiane Augusto de Mattos

A dinâmica das relações no norte de Moçambique no final do século XIX e início do século XX

res. ${ }^{27}$ Sharifs $s^{28}$ e chehes ${ }^{29}$ saíam dessas localidades para expandir a religião no norte de Moçambique, enquanto filhos de xeques e chefes para lá viajavam com o objetivo de receberem educação islâmica.

Há indícios da presença da religião islâmica, sobretudo entre as elites suaílis da costa, como as de Angoche, de Sofala, de Quelimane, das ilhas Querimbas e de Moçambique, desde o século VIII. ${ }^{30}$ A maior parte dos muçulmanos nessa região fazia parte da vertente sunita, seguindo a corrente Shafi'i, originária do sul da Arábia. ${ }^{31}$

A expansão do Islã entre as sociedades do interior, como a dos macuas, provocou algumas mudanças culturais, políticas e sociais. ${ }^{32} \mathrm{Um}$ exemplo disso foi o emprego da escrita árabe-suaíli, ensinada pelos mwalimu (professores), responsáveis pela educação da população nas escolas islâmicas, e observada nas correspondências trocadas entre os chefes e xeques do norte de Moçambique e os representantes do governo português. ${ }^{33} \mathrm{O}$ calendário muçulmano era também utilizado nessas cartas, a exemplo da missiva enviada pelo xeque da Matibane, Mamud Buana Amade Chivagy, ao comandante das Terras Firmes, cuja data era: "23 da lua Rabi'l'ackisi 1307".34

${ }^{27}$ ALPERS, E. East Africa and the Indian ocean. Princeton: Markus Wiener, 2009. ALPERS, E. East central Africa. In: LEVTZION, N. \& POUWELS, R. L. (eds.). The history of Islam in Africa. Atenas: Ohio University Press; Oxford: James Curry; Cape Town: David Philip, 2000, p. 303-327. PEARSON, M. N. Port cities and intruders: the Swahili coast, India, and Portugal in the early Modern era. Baltimore: The Johns Hopkins University Press, 1998.

${ }^{28}$ Significa "todo aquele que descende diretamente do Profeta". CARVALHO, Álvaro Pinto de. Notas para a história das confrarias islâmicas na ilha de Moçambique. Arquivo. Boletim do Arquivo Histórico de Moçambique. Maputo: Arquivo Histórico de Moçambique, 4, outubro de 1988, p. 65.

${ }^{29}$ Principal representante das confrarias.

${ }^{30}$ BONATE, Liazzat J. K., op. cit., 2007, p. 7. MACAGNO, Lorenzo. Les nouveaux oulémas. La recomposition des autorités musulmanes au nord du Mozambique. Lusotopie. Leiden: Brill, XIV, 1, maio 2007, p. 152. VILHENA, Ernesto Jardim de. Cia. do Nyassa. Relatório e memórias sobre os territórios. Lisboa: Typographia da "A Editora", 1906, p. 22.

${ }^{31}$ HAFKIN, Nancy, op. cit., 1973, p. 42.

${ }^{32}$ Sobre as transformações culturais provocadas pelo contato entre o islamismo e as práticas religiosas africanas é importante considerar: POUWELS, R. L. Horn and crescent: cultural change and traditional Islam in east African coast, 800-1900. Cambridge: Cambridge University Press, 1987. LEVTZION, N. \& POUWELS, R. L. (eds.). The history of Islam in Africa. Atenas: Ohio University Press; Oxford: James Curry; Cape Town: David Philip, 2000, p. 303-327.

33 VILHENA, Ernesto Jardim de, op. cit., 1906, p. 203.

${ }^{34}$ AHM, Fundo do século XIX, Governo Geral de Moçambique, 1890, caixa 8-149, maço 2. Ver também Correspondência de Molide Volay com data de 2 de lua 1310. AHM, Fundo do século XIX, Governo Geral de Moçambique, 1893, caixa 8-150, maço 1. Em correspondência do cheque de Sancul, Issufo Abdalá, ao governador geral de Moçambique, aparece a data "7 da 
rev. hist. (São Paulo), n. 171, p. 383-419, jul.-dez., 2014 http://dx.doi.org/10.11606/issn.2316-9141.rh.2014.89017
Regiane Augusto de Mattos

A dinâmica das relações no norte de Moçambique no final do século XIX e ińício do século XX

No final do século XIX, a expansão da educação islâmica atingia não somente as elites, mas alcançava também o restante da sociedade, incluindo as mulheres, sem, contudo, alterar completamente a identidade matrilinear das sociedades do interior do norte de Moçambique. ${ }^{35}$

O islamismo era professado em conjunto com as crenças locais, tendo ocorrido a convivência entre as duas, perceptível no caso dos "curandeiros" (mkulukwana), os quais se tornaram, com a conversão, também mwalimu. Continuavam com as suas funções de guardiões do conhecimento espiritual e ritual da genealogia e dos ancestrais. Todavia, passaram a exercer novas funções promovidas pela incorporação do livro sagrado (Alcorão), ocupando-se das escrituras, da educação islâmica e acompanhando as caravanas comerciais. ${ }^{36}$

A religião islâmica expandiu-se no norte de Moçambique por intermédio dasconfrariassufistas(turuq), quetinhamcomoprincipalrepresentanteochehe. Todo chehe recebe um documento escrito, denominado silsila, que representa uma rede genealógica de mestres e que lhe concede legitimidade como líder. ${ }^{37}$

No final do século XIX, existiam três confrarias islâmicas no norte de Moçambique levadas por habitantes das ilhas Comores, Madagascar e Zanzibar. A primeira delas foi a Rifa'iyya. August Nimtz Jr. afirma que, na segunda metade do século XIX, esta ordem estava presente na costa e também no interior da atual Tanzânia. Como o norte de Moçambique mantinha relações comerciais e culturais com essas regiões do Índico, pode-se inferir que a ordem Rifa'iyya se expandiu daí para o restante de Moçambique nesse mesmo período. ${ }^{38}$

Atualmente, na ilha de Moçambique, essa confraria é conhecida como Maulide que significa em árabe "aniversário do Profeta" (mawlide). Suas prin-

lua fichahary soffry 1302". AHM, Fundo do século XIX, Governo Geral de Moçambique, 1884, caixa 8-147, maço 2.

35 NEVES, F. A. da Silva. Informações acerca da capitania-mor de Angoche. Moçambique: Imprensa Nacional, 1901, p. 17.

${ }^{36}$ BONATE, Liazzat J. K. Matriliny, Islam and gender in northern Mozambique. Journal of Religion in Africa. Leiden: Brill, v. 2, 36, 2006, p. 139-166.

37 MACAGNO, Lorenzo. Islã, transe e liminaridade. Revista de Antropologia da USP. São Paulo: USP, 2007, v. 50, nº 1, p. 86. MACHADO, A. J. de Mello. Entre os macuas de Angoche. Lisboa, 1970, p. 275-278.

${ }^{38}$ BONATE, Liazzat, op. cit., 2007, p. 129-149. TRIMINGHAM, J. S. Islam in east Africa. Oxford: Clarendon Press, 1964. NIMTZ JR., A. Islam and politics in east Africa: the Sufi ordes in Tanzania. Minneapolis: Minnesota University Press, 1980. MEDEIROS, Eduardo. Irmandades muçulmanas no norte de Moçambique. In: ANGIUS, Matteo E ZAMPONI, Mario. Ilha de Moçambique: convergência de povos e culturas. AIEP editora, 1989. MEDEIROS, Eduardo. O Islão e a construção do "Espaço Cultural e Social Macua". In: RODRIGUES, José Damião \& RODRIGUES, Casimiro. Representações de África e dos africanos na história e cultura - séculos XV a XXI. Lisboa: Centro de História de Além-Mar, 2011, p. 195-280. 
rev. hist. (São Paulo), n. 171, p. 383-419, jul.-dez., 2014 http://dx.doi.org/10.11606/issn.2316-9141.rh.2014.89017
Regiane Augusto de Mattos

A dinâmica das relações no norte de Moçambique no final do século XIX e início do século XX

cipais características eram os rituais marcados por danças, cânticos, práticas de êxtase e transe em que os adeptos cravam estiletes nos corpos e no rosto. ${ }^{39}$

Pesquisadores já mostraram que, na atual Tanzânia, por exemplo, as confrarias islâmicas constituíram um dos fatores mais importantes da expansão da religião no interior e serviram, muitas vezes, de instrumento político e religioso por meio do qual uma chefia local demonstrava e consolidava a sua autoridade. Pertencer a uma confraria representava o acesso à dimensão dos ritos, o que transcendia a vida cotidiana, proporcionando poder e prestígio aos seus participantes. ${ }^{40}$

As ordens Shadhiliyya e Qadiriyya foram fundadas em Moçambique em 1897 e 1904, respectivamente em meio a um contexto de conquista militar e implementação da administração colonial de Portugal ${ }^{41} \mathrm{O}$ shehe da Qadiriyya, conhecido pelos portugueses como bispo muçulmano de Moçambique, residia na ilha de Moçambique. E o shehe da Shadhiliyya vivia em Angoche. ${ }^{42}$

Muitos líderes religiosos do Islã no norte de Moçambique eram também imigrantes das ilhas Comores ou de Madagascar, como o "Mualimo Xá Daudo, espécie de bispo, chefe dos mais padres monhés, aquele que os educa e os instrui nos segredos e práticas da religião". Ele teria chegado à região por volta de 1870 vindo de Ingagiza, em Madagascar. ${ }^{43}$

Da mesma forma que o sultanato de Angoche mantinha relações muito próximas com as elites muçulmanas de Zanzibar e das outras ilhas do Índico, há muito tempo preservando contatos de caráter religioso, há que se considerar igualmente o aspecto econômico de tais relações.

Zanzibar era uma das principais cidades comerciais do Índico, para onde se dirigiam comerciantes de várias localidades. As sociedades do interior levavam seus produtos até o litoral onde eram negociados por esses mercadores da costa. ${ }^{44}$ Em 1840, o sultão de Omã, Sayyid-Said, transferiu-se

\footnotetext{
${ }^{39}$ MACAGNO, Lorenzo, op. cit., v. 50, nº 1, 2007, p. 115. MATTOS, Regiane A. de. Islã e resistência: o sultanato de Angoche contra as tentativas de dominação portuguesa no norte de Moçambique. In: RIBEIRO, Alexandre Vieira \& GEBARA, Alexsander Lemos de Almeida (org.). Estudos africanos: múltiplas abordagens. $1^{\text {a }}$ edição. Niterói: Editora da UFF, 2013, p. 98-119.

${ }^{40}$ LE GUENNEC-COPPENS, Françoise E CAPLAN, Pat. Les Swahili entre Afrique et Arabie. Paris: Ed. Kathala, 1991, p. 53.

${ }^{41}$ CARVAlHO, Álvaro Pinto de, op. cit., p. 61-63.

${ }^{42}$ CASTRO, Soares de. Os Lómuès do Larde. Lourenço Marques: Sociedade de Estudos de Moçambique, 1952, p. 32-33. LUPI, Eduardo do Couto, op. cit., p. 223.

${ }^{43}$ NEVES, F. A. da Silva, op. cit., 1901, p. 22.

${ }^{44}$ VILHENA, Ernesto Jardim de, op. cit., 1906, p. 197. SHERIFF, Abdul. Slaves, spices and ivory in Zanzibar: integration of an east African commercial empire into the world economy, 1770-1873. Londres:
} 
rev. hist. (São Paulo), n. 171, p. 383-419, jul.-dez., 2014 http://dx.doi.org/10.11606/issn.2316-9141.rh.2014.89017
Regiane Augusto de Mattos

A dinâmica das relaç̃ões no norte de Moçambique no final do século XIX e início do século XX

para Zanzibar na tentativa de controlar esse comércio. ${ }^{45}$ A mudança aumentou a demanda por produtos e incentivos de Sayyid-Said, intensificando o comércio. Muitos comerciantes que costumavam ficar no litoral passaram a penetrar no continente em busca de mercadorias, o que contribuiu para as transformações sociais, políticas e econômicas, repercutindo na configuração do Islã na região. ${ }^{46} \mathrm{O}$ sultão Sayyid Said e mais tarde seus sucessores, sobretudo o sultão Bargash, aproveitaram as caravanas comerciais para construir redes políticas por meio da expansão do Islã e das confrarias islâmicas. ${ }^{47}$

Na mesma época, um processo semelhante pode ser observado no norte de Moçambique: os professores muçulmanos e também comerciantes acompanhavam as caravanas que viajavam pelo interior, aproveitando para expandir o Islã. As descrições feitas pelos viajantes europeus mostram que as sociedades macuas dependiam muito do comércio de marfim, escravos, borracha e objetos de ferro, como enxadas, facas e machados. O controle do comércio desses produtos proporcionava prestígio aos chefes, que adquiriam um status de distinção entre os demais e também por estarem próximos às principais localidades comerciais. Muitas caravanas de macuas se dirigiam para estes pontos comerciais levando sacos de arroz e borracha que trocavam, em particular, por tecidos que não tinham em sua região. ${ }^{48}$

A partir da década de 1840, algumas dessas sociedades do interior de macuas e também de yaos (ou ajauas) já apresentavam traços da cultura islâmica, tendo a religião ganhado força nessa área. Na década seguinte, o islamismo estava espalhado por todo o norte de Moçambique, sendo levado pelos yaos às Terras Altas do Chire, porém não muito além do sul do Zambeze. ${ }^{49}$

A expansão do Islã no norte de Moçambique pode ter sido realizada também pela influência do sultanato de Zanzibar na região. Em 1859, o

James Curvery, 1987. BENNET, Normam R. Zanzibar, Portugal e Moçambique: relações dos fins do século XVIII até 1890. Revista Internacional de Estudos Africanos. Lisboa, 6/7, jan.-jun. 1984. LE GUENNEC-COPPENS, Françoise (dir.), op. cit., 1991. PENRAD, Jean-Claude. Commerce et religion: expansion et configurations de l'Islam en Afrique oriental. O Islão na África Subsaariana. $6^{\circ}$ COLÓQUIO INTERNACIONAL. ESTADOS, PODERES E IDENTIDADES NA ÁFRICA SUBSAARIANA. Actas. Porto: Univ. do Porto, Centro de Estudos Africanos, 2004.

${ }^{45}$ LE GUENNEC-COPPENS, Françoise $\mathcal{E}$ CAPLAN, Pat, op. cit., p. 19.

${ }^{46}$ PENRAD, Jean-Claude, op. cit., 2004, p. 186.

${ }^{47}$ LE GUENNEC-COPPENS, Françoise E CAPLAN, Pat, op. cit., p. 19.

${ }^{48}$ GROVE, Daniel. África oriental portuguesa: A Macua. Boletim da Sociedade de Geografia de Lisboa. Lisboa, 1897. O'NEILL, Henry. África oriental portuguesa: Observações acerca da costa e do interior da província de Moçambique. Boletim da Sociedade de Geografia de Lisboa. Lisboa, 1882.

${ }^{49}$ NEWITT, Malyn, op. cit., 1997, p. 381. 
rev. hist. (São Paulo), n. 171, p. 383-419, jul.-dez., 2014 http://dx.doi.org/10.11606/issn.2316-9141.rh.2014.89017
Regiane Augusto de Mattos

A dinâmica das relações no norte de Moçambique no final do século XIX e início do século XX

governador geral de Moçambique, João Tavares de Almeida, considerava o sultão de Angoche de fato independente do governo português e procurava atrair para o seu lado "árabes, mujojos e outros moiros das ilhas ao norte desta província, da mais ínfima classe, ou antes verdadeiros piratas e traficantes de Zanzibar, crescendo com este auxílio, em força e audácia". Afirmava também que o sultão de Angoche recebia a proteção do imã de Mascate e agora passava a recebê-la do sultão de Zanzibar que, por sua vez, fazia isso porque tinha interesses comerciais e religiosos, já que era muçulmano. ${ }^{50}$

A relação com Zanzibar e com as ilhas Comores era importante no que se refere à educação islâmica. Os chefes e xeques costumavam enviar para lá seus filhos para estudarem em escolas islâmicas, como o xeque de Quitangonha que mandou, em 1830, um de seus filhos para as ilhas Comores. Da mesma maneira, o xeque de Sancul fez questão de que, em 1878, seu filho fosse educado em Mohilla, nas ilhas Comores..$^{51}$ Exemplares do livro sagrado, o Alcorão, chegavam também da Arábia, por intermédio das livrarias de Zanzibar. ${ }^{52}$

Os sharifs formavam uma categoria social muito particular, responsáveis pela introdução da educação islâmica, das escolas corânicas, pela tradição literária e pela escritura de livros. Ainda assim estavam envolvidos com o comércio, criando redes comerciais entre a costa e as ilhas do Índico. Em sua maior parte, eram originários da península Arábica - Mascate, Omã ou Iêmen - e permaneceram na costa suaíli, sobretudo em Pate, Lamu, Zanzibar e Comores. ${ }^{53}$

Como procurei demonstrar, as sociedades do norte de Moçambique, sobretudo o sultanato de Angoche, mantinham relações próximas com as elites mercantis muçulmanas de Zanzibar e das outras ilhas do Índico, assim como com as localizadas no interior do continente. Fazer parte desse complexo de interconexões pressupunha a manutenção de contatos constantes e a instituição de redes sociais, políticas, econômicas e culturais, o que contri-

\footnotetext{
${ }^{50}$ AHU, Semu, DGU. Correspondência dos governadores, Moçambique, 8 de agosto de 1859, caixa 1305, pasta 23, capilha 2, documento 53. Ver também: AHU, Semu, DGU. Correspondência dos governadores, Moçambique, 18 de setembro de 1859, caixa 1305, pasta 23, capilha 3, documento 106. Mujojo era a designação utilizada para se referir ao "comerciante suahili oriundo nomeadamente das ilhas Madagáscar e Comores, que frequentava os portos de Moçambique". CAPELA, José. Como as aringas de Moçambique se transformaram em quilombos. Tempo. Revista do Departamento de História da UFF. Rio de Janeiro: 7 Letras, v. 10, nº 20, jan-jun 2006, p. 83-108. ${ }^{51}$ NEVES, F. A. da Silva, op. cit., 1901, p. 16.

52 PEIRONE, Federico. Correntes islâmicas moçambicanas. Lisboa: [s.n., D. L. 1964], p. 6. ALPERS, E. Complex relationship: Mozambique and the Comoro islands in the $19^{\text {th }}$ and $20^{\text {th }}$ centuries. In: East Africa and the Indian ocean. Princeton: Markus Wiener, 2009.

${ }^{53}$ LE GUENNEC-COPPENS, Françoise \& CAPLAN, Pat, op. cit., p. 41.
} 
buiu para a mobilização tanto das chefias do norte de Moçambique como de agentes de diferentes camadas sociais: soldados desertores, guias, carregadores, proprietários de terras de origem portuguesa ou indiana (muzungos), facilitando a construção de laços de lealdade entre elas, acionados em momentos de crise, como, por exemplo, diante das investidas do governo português na região, e resultando no intercâmbio de armas, munições e guerreiros e ataques simultâneos aos postos administrativos e militares portugueses.

\section{Principais fatores desencadeadores da "resistência"}

No que se refere aos fatores desencadeadores das ações da "coligação de resistência", segundo a tradicional historiografia sobre o tema, a proibição do comércio de escravos foi o elemento primordial para a organização das ações realizadas no final do século XIX contra o governo português.

Caminhando muitas vezes na contramão dessa historiografia, procurei demonstrar que o principal objetivo dessas sociedades era a preservação da sua autonomia política, ameaçada pelas iniciativas de controle do comércio e da produção de gêneros agrícolas e de extração, de implementação da cobrança de impostos e do trabalho compulsório.

Para a manutenção da autonomia política dessas sociedades localizadas no litoral norte de Moçambique, como o sultanato de Angoche, era fundamental preservar a autonomia econômica tendo em vista o seu papel no espaço de trocas comerciais na África oriental realizadas por meio do oceano Índico. Contudo, a autonomia econômica era garantida não apenas pelo comércio de escravos, mas pelo controle das rotas comerciais estabelecidas entre o litoral do oceano Índico e o interior pelas quais eram transportados outros produtos.

\subsection{Controle do comércio e da produção de gêneros agrícolas e de extração}

É preciso lembrar como apontaram José Capela, Eduardo Medeiros e Joseph Mbwiliza que, ao mesmo tempo em que o comércio de escravos entrava numa fase de declínio, apesar de ainda ser realizado pelos chefes locais, a produção e o comércio de produtos agrícolas e de extração, tais como borracha, goma copal e amendoim, aumentou significativamente no final do 
rev. hist. (São Paulo), n. 171, p. 383-419, jul.-dez., 2014 http://dx.doi.org/10.11606/issn.2316-9141.rh.2014.89017
Regiane Augusto de Mattos

A dinâmica das relações no norte de Moçambique no final do século XIX e início do século XX

século XIX. ${ }^{54} \mathrm{O}$ poder e a autoridade dos chefes do litoral, vinculados ao controle da produção destes gêneros e à sua comercialização realizada entre o litoral do Índico e as sociedades do interior, passaram a ser ameaçados pelas iniciativas portuguesas de instalação de postos militares no continente, de cobrança de impostos sobre os produtos e de incentivo aos indianos como intermediários comerciais, que passaram a concorrer com esses chefes locais.

Entretanto, vale mencionar que o comércio de escravos foi um dos mais lucrativos negócios realizados nos portos de Moçambique desde o século XVII. ${ }^{55}$ E Angoche tornou-se um dos mais importantes centros econômicos dessa região a partir de meados do século XVIII, quando o tráfico de escravos ganhou força com os crescentes incentivos portugueses. Assim, já no início do século XIX, era um dos principais pontos comerciais de escravos da África oriental frequentados por mercadores árabes, persas, indianos, franceses, portugueses e brasileiros. ${ }^{56}$ À época do tráfico "clandestino", houve intensificação da captura, sobretudo na área sob o domínio do sultanato de Angoche, sendo esta uma das mais frequentadas por comerciantes de escravos.

Além de proporcionar às chefias locais prestígio, riquezas e produtos como armas e pólvora, o comércio de escravos contribuiu para o fortalecimento de determinadas sociedades, como o sultanato de Angoche, fazendo com que este dominasse uma rede comercial importantíssima. Os chefes de Angoche já eram os principais intermediários comerciais entre o interior e a costa do Índico, devido ao comércio de escravos, e seu poder e sua prosperidade passaram a depender do domínio da produção e do comércio agora também de produtos agrícolas e de extração.

É preciso lembrar que a expansão política e econômica de Angoche ocorreu, igualmente, em meados do século XIX, com a incorporação de novos territórios sob a influência do sultanato. ${ }^{57}$ Esses territórios eram estra-

${ }^{54}$ MEDEIROS, Eduardo. As etapas da escravatura no norte de Moçambique. Maputo: Arquivo Histórico de Moçambique, 1988, p. 49-51. MBWILIZA, Joseph F. A history of commodity production in Makuani, 1600-1900. Dar es Salaam: Dar es Salaam University Press, 1991, p. 120.

${ }^{5}$ CAPELA, José \& MEDEIROS, Eduardo. O tráfico de escravos nos portos de Moçambique. Porto: Edições Afrontamento, 2002. RITA-FERREIRA, Antonio. Fixação portuguesa e história pré-colonial de Moçambique. Lisboa: Instituto de Investigação Científica Tropical/Junta de Investigações Científicas do Ultramar, 1982, p. 19-20. CAMPBELL, Gwyn. Madagascar and Mozambique in slave trade of the western Indian ocean, 1800-1861. Slavery $\mathcal{E}$ Abolition, no 9, 1988, p. 166-193.

${ }^{56}$ RITA-FERREIRA, Antonio, op. cit., 1982, p. 124, 156, 301. CLARENCE-SMITH, William. The economics of the Indian ocean slave trade in the nineteenth century. Londres: Frank Cass, 1989.

57 De acordo com Pedro Massano de Amorim, a região entre os rios M'luli e Larde era formada por terras fertéis, onde os chefes da ilha de Angoche mantinham as suas plantações. Ademais, 
rev. hist. (São Paulo), n. 171, p. 383-419, jul.-dez., 2014 http://dx.doi.org/10.11606/issn.2316-9141.rh.2014.89017
Regiane Augusto de Mattos

A dinâmica das relações no norte de Moçambique no final do século XIX e início do século XX

tegicamente importantes porque, além de férteis para a produção agrícola, estavam localizados entre a costa do Índico e o interior do continente, constituindo uma barreira aos chefes das caravanas que vinham do interior para trocar as suas mercadorias. Por essa razão, para garantir a autonomia política e econômica do sultanato, era fundamental que os chefes de Angoche continuassem desempenhando a função de intermediários, preservando em suas mãos o controle desse comércio.

Nas últimas décadas do século XIX, o controle do comércio de produtos agrícolas estava sendo ameaçado por algumas ações do governo português. A partir da instalação de postos militares nas povoações do continente, as autoridades portuguesas tentavam obter para si o controle desse comércio, cobrando impostos sobre os produtos vendidos e emitindo licenças para a instalação de lojas aos comerciantes indianos, incentivando assim a concorrência desses intermediários com os chefes suális e macuas. ${ }^{58}$

Eduardo Lupi, que foi capitão-mor de Angoche entre 1903 e 1905, explica que os "monhés de Angoche" passaram a intermediar o comércio desde que o governo português proibira a entrada de chefes das caravanas do interior que se dirigiam à região próxima ao posto português no Parapato para negociar a sua produção. É preciso, contudo, relativizar tal informação dada por Lupi, na medida em que, independentemente da "proibição" da entrada dos chefes do interior, os sultões de Angoche sempre foram retratados como intermediários comerciais, realizando a expansão política do sultanato, notadamente a partir do desempenho dessa função na economia da região.

Todavia, Lupi mostra que o principal conflito nas relações entre Angoche e o governo português estava circunscrito à intermediação do comércio. Afirma que, no final do século XIX, as autoridades portuguesas passaram a frequentar as povoações dos macuas do interior, incentivando o contato direto e a eliminação dos chefes de Angoche como intermediários..$^{59}$

os chefes dessa região eram subordinados ao sultão de Angoche. AMORIM, Pedro Massano de, op. cit., p. 40-41. "O sultão do M'luli, cuja residência era na povoação de Catamoio, não dava nenhuma proteção [ao governo português] ao comércio no interior." AHU, Semu, DGU. Correspondência dos governadores, Moçambique, 1884, caixa 1327, capilha 1 documento 74. ${ }^{58}$ MEDEIROS, Eduardo, op. cit., 1988, p. 49-51. MBWILIZA, Joseph F., op. cit., p. 120.

59 "Mas da borda d'água até um e mesmo dois dias de marcha, têm eles [monhés de Angoche] procurado sempre tornar-se os intermediários entre as caravanas do interior e os estabelecimentos comerciais, que fazem a permuta dos gêneros de cultura indígena pelos algodões. Sobretudo na época em que vigorava a peregrina orientação administrativa e política de não permitir a entrada dos macuas, na limitada zona efetivamente ocupada por nós - o que se restringia à vila Antonio Ennes - quando vinham fazer o seu negócio, sob a poderosa razão de 
rev. hist. (São Paulo), n. 171, p. 383-419, jul.-dez., 2014 http://dx.doi.org/10.11606/issn.2316-9141.rh.2014.89017
Regiane Augusto de Mattos

A dinâmica das relaç̃oes no norte de Moçambique no final do século XIX e início do século XX

Mahamuieva ou Omar Bin Nacogo Farrahali, mais conhecido como Farelay, é apresentado nas fontes documentais estudadas como o líder da "coligação de resistência". Era "sobrinho-neto" dos antigos sultões de Angoche, Mussa Quanto e Ussene Ibrahimo, e um dos inhabacos de Angoche, isto é membro do clã matrilinear do sultanato. ${ }^{60}$ Em 1902, Farelay foi eleito "sultão" de M'luli e Larde, territórios no continente que faziam parte das principais rotas das caravanas comerciais e da esfera política do sultanato.

Ele partia dos territórios do interior com o objetivo de continuar a tarefa de "bloquear a vila de Parapato" e cobrar tributos das caravanas vindas do interior para ali permutar e voltar com fazendas, e dos comerciantes indianos que estabeleciam suas lojas naquele local. ${ }^{61}$ Eduardo Lupi deixou o seguinte relato a respeito das ações de Farelay:

Chega ao máximo grau possível o seu arrojo, assim como a nossa inação. Todos os anos, no começo da temporada da permuta, vem grande pompa até as portas da vila, a meia légua apenas da residência dos governadores. E fazendo ir ahi, a estes ou aos

não serem nossos amigos - e nenhuns o eram porque nenhuns nos conheciam - os muinhé de Angoche insinuando-se como indispensáveis intermediários, trocando a preços desanimadores para os negros os produtos que este trazia pelos algodões e contaria que os indianos lhe forneciam a crédito, faziam um negócio ativo e rendosíssimo. Às terras de Matadane, na zona litoral, compreendida entre o Lardy e Moma, iam também comprar ou extrair quantidades avultadas de borracha. Ultimamente, porém, depois que foi posta de parte a proibição que acima ficou indicada, por efeito da confiança que os macuas começaram a ter em nós, ao verem-se bem recebidos na vila, assim como ao verem-se visitados nas suas povoações do interior e convidados a retribuir livremente essas visitas, essa mesma ação comercial foi sendo notavelmente reduzida, podendo mesmo prever-se para muito breve o seu completo desaparecimento." LUPI, Eduardo do Couto, op. cit., p. 175-176.

${ }^{60}$ De acordo com a tradição oral recolhida por Eduardo Lupi, no início do século XX, o sultanato era formado por quatro linhagens, simbolizadas pelos quatro filhos do fundador, um imigrante muçulmano, e sua esposa macua: inhanandare, inhamilala, inhaitide e m'bilinzi. A linhagem inhanandare era considerada a fundadora do sultanato, representada pelo primeiro filho e herdeiro do fundador imigrante, seguia o sistema de parentesco patrilinear. Os sultões de Angoche eram escolhidos entre os membros dessa linhagem, cujo reduto era a povoação de Muchelele na ilha de Angoche. As outras três linhagens (inhamilala, inhaitide e m'bilinzi) estabelecidas em Catamoio, formavam o clã inhabaco, que representava o lado macua da esposa do fundador, seguindo o sistema de parentesco matrilinear e se alternavam nos principais cargos do sultanato: sultão, vizir e capitão-mor. LUPI, Eduardo do Couto, op. cit., 1907, p. 162-163.

${ }_{61}$ "O Farelay deu-nos que fazer, embora sem ter a envergadura do Mussá-Quanto e longe de ter a sua proverbial valentia. Era inteligente, manhoso e atrevido, e conhecia bem a inanidade da nossa ocupação em Angoche, visto que frequentemente ia ao Parapato. Usava dos processos do Ussene bloqueando o Parapato e cobrando pesados impostos de quem, viajantes ou caravanas, pretendesse atingi-lo vindo do interior, e instalava a sua residência a 5 quilómetros da vila". COUTINHO, João de Azevedo. As duas conquistas de Angoche. Lisboa: Pelo Império, 11, 1935, p. 20. 
rev. hist. (São Paulo), n. 171, p. 383-419, jul.-dez., 2014 http://dx.doi.org/10.11606/issn.2316-9141.rh.2014.89017
Regiane Augusto de Mattos

A dinâmica das relações no norte de Moçambique no final do século XIX e início do século XX

seus delegados, assim como aos principais negociantes, fixa o preço pelo qual consente na abertura dos caminhos que as caravanas seguem, assim como a boca que cada loja indiana tem que pagar-lhe naquele anno. ${ }^{62}$

Como as autoridades portuguesas, nesse momento, passaram a ter acesso direto aos produtos vindos do interior, a estratégia utilizada para manter o controle desse comércio por Farelay, como representante das sociedades historicamente intermediárias comerciais, foi a cobrança de "impostos" dos chefes das caravanas e também dos negociantes estabelecidos em lojas. ${ }^{63}$

Conhecedor desses fatos, o governo português promovia ataques aos chefes do M'luli e do Larde, principais territórios de passagem das caravanas, na tentativa de lhes retirar o controle do comércio, além de incentivar os chefes do interior a procurarem os postos portugueses para trocar as suas mercadorias, e de liberar licenças, com a cobrança de taxas, para que os negociantes indianos estabelecessem lojas comerciais nesses territórios.

Farelay construiu um acampamento fortemente cercado por paliçadas chamado de "n'ringa" (aringa) num local de passagem entre os rios M'pirigoma e Mutuguti a aproximadamente cinquenta quilômetros do Parapato. Estabeleceu também pequenos postos de observação ao longo do caminho, de onde "amigos de outros tempos" avisavam-lhe o que acontecia. ${ }^{64}$ A residência de Farelay foi invadida em 1903 e queimada pelo governo português, mas Farelay e sua população já tinham se retirado do local. ${ }^{65}$

Em 1893, é possível notar o apoio dado por Farelay à M'Fatima (ou Nuno Fatima) Bin Zacharias, considerada a pia-mwene de Kinga (ou Seremage), na área de Sangage. ${ }^{66}$ As mulheres, sobretudo as pia-mwene, ${ }^{67}$ representantes das

\footnotetext{
${ }^{62}$ LUPI, Eduardo do Couto, op. cit., 1907, p. 213.

63 AHM, Fundo do século XIX, Governo Geral de Moçambique, 1895, caixa 8-105, maço 3. “Chegava a insolência destes bandidos - que crescia porque não eram castigados - a ponto de virem ao Parapato, a pouca distância da residência do governador, impor aos comerciantes condições para lhes deixar passar as fazendas e mercadorias ou os produtos que as caravanas traziam do interior." AMORIM, Pedro Massano de, op. cit., p. 14.

${ }^{64}$ LUPI, Eduardo do Couto, op. cit., 1907, p. 211.

${ }^{65}$ COUTINHO, João de Azevedo, op. cit., 1941, p. 556-557.

${ }^{66}$ Correspondência do comandante militar de Moginqual a Nuno Fatima. Moginqual, 11 de maio de 1893. AHM, Fundo do século XIX, Governo Geral de Moçambique, 1893, caixa 8-156, maço 1.

${ }^{67}$ Nas sociedades matrilineares macuas do norte de Moçambique, a mulher mais velha do grupo de anciãs era chamada de apwya - "a mulher que nos alimentou a todos". Tinha a função de conservar a memória da linhagem e estabelecer a ligação com os seus ancestrais. Participava de vários momentos e cerimônias significativos da comunidade, como os rituais de iniciação, fúnebres e de guerra. A escolha do novo chefe deveria necessariamente receber a aprovação
} 
rev. hist. (São Paulo), n. 171, p. 383-419, jul.-dez., 2014 http://dx.doi.org/10.11606/issn.2316-9141.rh.2014.89017
Regiane Augusto de Mattos

A dinâmica das relações no norte de Moçambique no final do século XIX e início do século XX

linhagens nas sociedades matrilineares, questionavam, por exemplo, a interferência do governo português nos processos sucessórios ao ignorar a importância de uma das principais funções das pia-mwene, quando, então, as autoridades portuguesas apoiavam e legitimavam o poder dos ainda concorrentes aos cargos de chefe e capitão-mor, antes mesmo da sua aprovação. ${ }^{68}$

Como demonstração das funções de uma verdadeira pia-mwene, em 1891, M'Fatima comunicava ao governo português que após a morte de seu filho, xeque Che Agy, escolhera Selemane bin Mocombotas para ocupar o cargo. ${ }^{69}$ O novo xeque Mocombotas ou Che $\mathrm{Agy}^{70}$ foi rapidamente reconhecido pelo governo português.

Entretanto, em 1893, Selemane Bin Mocombotas foi "tirado" do cargo e substituído por Sheagy Bin Aly, nomeado pelo governo português. ${ }^{71}$ Algumas exigências e ameaças feitas por Mocombotas numa carta escrita logo depois da sua posse, em 1891, podem explicar esta mudança de atitude do governo português. Endereçada ao comandante militar de Moginqual, João Augusto Soares de Castro Cabral, Age Selemane [Ibraimo] Aly [M'computo] ou Che-Agy solicitava que lhe enviassem alguns produtos como fazenda branca (chamada de americana), piri-piri (pimenta), cominhos, açúcar, manteiga, tâmaras e tecidos de algodão. Por fim, o xeque ainda ameaçou o comandante militar escrevendo: "Estamos com Pharelai e outro Mussilimague. Senhor Mussa, não faça brincadeira porque aqui veio aqui Pharelai. Não tenha duvida você deste individuo".72

e a legitimação da pia-mwene, por meio do ritual de investidura. GEFFRAY, C. Nem pai nem mãe. Crítica de parentesco: o caso de Macua. Maputo: Editorial Ndjira; Lisboa: Editorial Caminho, 2000.

${ }^{68}$ Vale pontuar a apropriação por algumas sociedades do norte de Moçambique do termo "capitão-mor" originário da administração portuguesa. É possível perceber que nas sociedades africanas este cargo era ocupado pelo responsável por assuntos de política externa. Muitas vezes, o governo português em Moçambique reconhecia a legitimidade dos eleitos aos cargos políticos e administrativos africanos, inclusive os de capitão-mor, publicando a sua "nomeação" nos Boletins Oficiais da Província de Moçambique.

69 Correspondência do comandante militar de Moginqual ao secretário geral do Governo Geral de Moçambique. Moginqual, 12 de janeiro de 1891. AHM, Fundo do século XIX, Governo Geral de Moçambique, 1891, caixa 8-151, maço 1.

${ }^{70}$ Che Agy era o termo político hereditário.

${ }^{71}$ Correspondência do comandante militar de Moginqual a M'Fatima. Moginqual, 11 de maio de 1893. AHM, Fundo do século XIX, Governo Geral de Moçambique, 1893, caixa 8-156, maço 1.

${ }^{72}$ Correspondência do xeque Che Agy ao comandante militar do Moginqual. Moginqual, 10 de abril de 1891 (data do envio da carta em árabe ao secretário geral). AHM, Fundo do século XIX, Governo Geral de Moçambique, 1891, caixa 8-151, maço 1. 
rev. hist. (São Paulo), n. 171, p. 383-419, jul.-dez., 2014 http://dx.doi.org/10.11606/issn.2316-9141.rh.2014.89017
Regiane Augusto de Mattos

A dinâmica das relações no norte de Mocambique no final do século XIX e iníio do século XX

Pode-se supor que Mocombotas (Che Agy) solicitasse o envio dos produtos importados (tecidos, pimenta e açúcar) ao governo português por ser um dos chefes responsáveis pela intermediação comercial entre o interior do continente e o litoral do Índico. Os chefes de caravanas do interior entregavam gêneros agrícolas e de extração a chefes como Mocombotas e Farelay que exerciam a função de intermediários comerciais, enquanto os negociantes estrangeiros que desembarcavam na costa do Índico ou os proprietários das lojas comerciais e o governo português forneciam em troca produtos vindos de fora do continente. Com o objetivo de minar o poder de Che Agy como intermediário comercial, que era fortalecido pelo apoio de Farelay, o governo português aliou-se a Sheagy (xeque de Mutucura, provavelmente concorrente ao mesmo papel de intermediário comercial), reconhecendo-o como o xeque legítimo da região.

Além de concorrer no controle do comércio de gêneros agrícolas nas terras sob influência do sultanato de Angoche, o governo português organizou ataques aos chefes da região e expedições militares às terras dos chefes do grupo chamado namarrais, localizados nos territórios do continente em frente à ilha de Moçambique, os quais também exerciam controle sobre esse comércio por estarem nas rotas das caravanas que se dirigiam a outro posto português na ilha de Moçambique. As autoridades portuguesas também investiam cada vez mais na instalação de postos militares no continente, procurando instituir a cobrança do imposto da palhota nessas povoações. ${ }^{73}$

O governo português organizou a primeira expedição militar contra os namarrais em setembro de 1888, apresentando como justificativa o fato dos namarrais escravizarem e assassinarem gentes das populações do "continente fronteiro" (as chamadas Terras Firmes) à ilha de Moçambique. ${ }^{74}$

Entretanto, uma informação divulgada pelo governador geral de Moçambique pode esclarecer outras razões para essa expedição militar. Segundo o governador, o chefe namarral Selimo era "um verdadeiro salteador" que

\footnotetext{
73 O imposto da palhota incidia sobre cada habitação e podia ser pago em moeda, gênero agrícola ou em trabalho. Era um dos principais mecanismos coloniais, pois inseria as populações africanas nas atividades econômicas coloniais e, consequentemente, regulamentava a utilização da sua força de trabalho. MARTINS, Luísa F. G. A expedição militar portuguesa ao Infusse em 1880. Um exemplo de ocupação colonial nas terras islamizadas do norte de Moçambique. REUNIÃO INTERNACIONAL DE HISTÓRIA DE ÁFRICA: RELAÇÃO EUROPA-ÁFRICA NO $3^{\circ}$ QUARTEL DO SÉCULO XIX. Anais. Lisboa: Centro de Estudos de História e Cartografia Antiga, Instituto de Investigação Científica e Tropical, 1989.

${ }^{74}$ AHU, Semu, DGU, 1888, caixa 1331, pasta10, capilha 2, documento147.
} 
rev. hist. (São Paulo), n. 171, p. 383-419, jul.-dez., 2014 http://dx.doi.org/10.11606/issn.2316-9141.rh.2014.89017
Regiane Augusto de Mattos

A dinâmica das relações no norte de Moçambique no final do século XIX e início do século XX

dava refúgio em suas terras aos "malfeitores escapados às justiças" e, estando no caminho das principais rotas comerciais em direção ao interior, cobrava altas taxas para a realização desse comércio. ${ }^{75}$

Assim como Farelay e os chefes do M'luli e do Larde, os namarrais detinham o controle das rotas comerciais dos produtos agrícolas e de coleta que eram trazidos do interior pelos chefes macuas. Os namarrais teriam sido chefes de caravanas que se fixaram no território entre Monapo e Fernão Veloso na primeira metade do século XIX, estabelecendo-se como uma entidade política por meio de relações com os chefes da costa e como intermediários comerciais com as sociedades do interior. ${ }^{76}$

Entretanto, a constituição de agrupamentos e chefias fortemente militarizadas poderiam também ameaçar a presença dos portugueses e as suas iniciativas de instituição dos mecanismos coloniais na região. É preciso considerar que os namarrais incorporaram, por meio de laços de lealdade, as populações de escravos fugidos da ilha de Moçambique que compunham a aringa de Ampapa. Seguindo a análise de José Capela, as aringas poderiam ser formadas por escravos guerreiros (denominados achikundas) e colonos (população não escrava) dos prazos da região do vale do Zambeze que migraram na primeira metade do século XIX e por soldados desertores das forças portuguesas. ${ }^{77}$ Esse fato pode ter contribuído para o caráter fortemente militarizado que os namarrais apresentavam na segunda metade do século XIX.

Os namarrais tinham estabelecido relações de lealdade com o comandante militar e depois capitão-mor de Sancul de nome Marave, um chefe que também detinha conhecimentos de estratégias de guerra, contribuindo ainda mais para a militarização dos namarrais. ${ }^{78}$

Em 1896, o governador geral de Moçambique, Mouzinho de Albuquerque, enviou a segunda expedição militar ao território dos namarrais. Contra esta os namarrais receberam a ajuda de Marave e de alguns muzungos. ${ }^{79}$

Joaquim Ignácio de Souza (advogado e proprietário), Francisco Maria Paixão Dias (oficial da secretaria geral e proprietário), Ballá Saunto (proprie-

\footnotetext{
75 AHM, códice 11-29, folhas 43 e seguintes, do governador-geral para o ministro, 26 de abril de 1886. Apud CAPELA, José, op. cit., 2006, p. 90.

${ }^{76}$ MARTINS, Luísa F. G. Os namarrais do antigo distrito de Moçambique: percursos identitários e resistências (18571913). Tese de doutorado, Universidade de Évora, 2010. MARTINS, Luísa F. G., op. cit” 1989, p. 490.

77 CAPELA, José, op. cit., 2006, p. 86-90. MARTINS, Luísa, op. cit., 2011.

${ }^{78}$ Vale lembrar, como ressaltou Joseph Mbwiliza, que, a partir da década de 1850, surge uma nova geração de líderes militarizados no norte de Moçambique. MBWILIZA, Joseph F., op. cit., 1991, p. 144.

${ }^{79}$ LUPI, Eduardo do Couto, op. cit., 1907, p. 214-215.
} 
rev. hist. (São Paulo), n. 171, p. 383-419, jul.-dez., 2014 http://dx.doi.org/10.11606/issn.2316-9141.rh.2014.89017
Regiane Augusto de Mattos

A dinâmica das relações no norte de Mocambique no final do século XIX e iníio do século XX

tário), Dagy Saunto (proprietário) e Abude Bine Assane Sualé (oficial de diligências do Juízo da Comarca de Moçambique) foram presos sob a acusação de "cúmplices da rebelião" por fornecerem armas e pólvoras ao Marave e aos chefes namarrais, e condenados ao degredo. ${ }^{80}$

Em seu relato, Mouzinho continua enumerando as razões da coligação entre muzungos e o Marave sem deixar de fazer referência ao interesse no tráfico de escravos. Todavia, alega que a cobrança de imposto constituiu igualmente um dos fatores desencadeadores das ações organizadas. ${ }^{81}$ Podese supor que, como proprietários de terras, os muzungos não aceitassem a intervenção do governo português em sua produção de gêneros agrícolas, na desestruturação das redes comerciais e na cobrança de impostos sobre esses produtos e sobre o trabalho empregado em suas terras.

Dessa maneira, a "coligação de resistência" abrangia diferentes sociedades ao longo de um território significativo, estendendo-se até Moma, com ações combinadas entre Marave de Sancul, Farelay de Angoche, M'Fatima de Kinga, os namarrais e os muzungos.

\subsection{Exploração de minérios, cobrança de impostos e trabalho compulsório}

A exploração de minérios, a cobrança de impostos e o trabalho compulsório, mecanismos promovidos pelas autoridades portuguesas, também podem ser apresentados como fatores que desencadearam as ações de resistência no norte de Moçambique. No final do século XIX, a região da Imbamela foi alvo de interesses dos ingleses que para lá se dirigiram em busca de territórios para exploração, sobretudo de metais preciosos. Por volta de 1897, o geólogo inglês Daniel Grove, que realizava estudos na colônia do Cabo e em Bechuanalândia (atual Botsuana), foi encarregado por Henrique Alfredo

\footnotetext{
${ }^{80}$ Praça de S. Sebastião em Moçambique, 6 de agosto de 1899. AHU, caixa 1552, Moçambique, 1901-1902, pasta $n^{\circ} 2$, processo n. 46.

81 "É claro que nada convém a estes mercadores que se estabeleça a soberania portuguesa nestas paragens. Acresce isto à obrigação de pagar impostos, que todos desagrada e que só agora se levou a efeito (...). Creio que logo que eu fui nomeado governador geral, pelo menos logo que cheguei, esta gente percebeu que tinha que acabar toda e qualquer proteção aos bandidos do continente; juntou-se a alguns outros fatos que levaram essa gente a juntar-se com o fim principal de me embaraçar o governo por todas as formas; a que lhes pareceu mais simples e eficaz foi auxiliar os rebeldes dando-lhes armas, munições, e trazendo-os sempre bem informados (...) Sendo eu demitido do governo, confiavam que voltaria isto aos antigos tempos. Se eu fosse morto melhor ainda." Mouzinho de Albuquerque. In: LUPI, Eduardo do Couto, op. cit., 1907, p. 216.
} 
rev. hist. (São Paulo), n. 171, p. 383-419, jul.-dez., 2014 http://dx.doi.org/10.11606/issn.2316-9141.rh.2014.89017
Regiane Augusto de Mattos

A dinâmica das relações no norte de Moçambique no final do século XIX e início do século XX

Ward, da Kimberley Diamond Fields, de fazer uma inspeção na região do norte de Moçambique conhecida como "Macua". A expedição teria como guia Arthur Guilherme Brodkin que, dois anos antes, já havia percorrido o trecho de Moçambique até o território dos imbamelas. ${ }^{82}$

Em abril de 1894, o comandante militar de Angoche relatava a viagem de Brodkin a Imbamela, cujo objetivo era negociar o seu estabelecimento no local para exploração daquelas terras. O chefe Morla-muno recebeu-o muito bem e mandou que três homens o acompanhassem na viagem de volta até o porto de Natal, em Durban. Brodkin fez várias observações sobre o terreno, certificando-se da existência de minas de diferentes metais na região. ${ }^{83}$

Para realizar a expedição ao interior de Moçambique, a equipe deveria obter das autoridades portuguesas uma espécie de passaporte de circulação. Para consegui-lo, Grove apresentou como justificativa para a viagem a importância de se obter uma declaração de submissão e de compromisso de lutar em caso de guerra ao lado dos portugueses, tendo em vista que o chefe Morla-muno poderia dispor de quarenta mil homens armados. Além disso, no início do século $\mathrm{XX}$, o governo português havia iniciado um conflito ao negar o envio de auxílio numa guerra ao Morla-muno que, por sua vez, exigia a entrega de armas e munições pelos serviços prestados ao governo pelo seu antecessor. Dessa maneira, rompia-se a aliança "luso-imbamela" de várias décadas. ${ }^{84}$ Por essa razão, a assinatura do tratado de vassalagem obtida por intermédio de Daniel Grove era importante para o governo português restabelecer a aliança estratégica com um dos mais importantes chefes de uma das regiões ricas em minérios. ${ }^{85}$ Com a aprovação das autoridades portuguesas, Grove e sua equipe deram início à viagem para a Imbamela que resultou na obtenção da declaração de submissão do chefe dos imbamelas às autoridades portuguesas. ${ }^{86}$

Entretanto, havia outros interesses na região da Imbamela revelados numa carta do comandante militar de Angoche ao secretário geral do gover-

${ }^{82}$ GROVE, Daniel, op. cit., 1897.

${ }^{83}$ Correspondência do comandante militar de Angoche ao secretário geral do Governo Geral de Moçambique. Antonio Ennes, 21 de abril de 1894. AHM, Fundo do século XIX, Governo Geral de Moçambique, 1894, caixa 8-105, maço 2.

${ }^{84}$ LUPI, Eduardo do Couto, op. cit., 1907, p. 204-206.

85 GROVE, Daniel, op. cit., p. 131-132.

${ }^{86}$ Daniel Grove relata que, antes de chegar à sede do Morla-muno, a expedição passou pelas povoações de diferentes "chefes subalternos", para os quais teve de distribuir mantimentos, tecidos e drogas farmacêuticas como tributos por transitar em seus territórios. GROVE, Daniel, op. cit., p. 130. 
rev. hist. (São Paulo), n. 171, p. 383-419, jul.-dez., 2014 http://dx.doi.org/10.11606/issn.2316-9141.rh.2014.89017
Regiane Augusto de Mattos

A dinâmica das relações no norte de Moçambique no final do século XIX e iníio do século XX

no de Moçambique com informações sobre uma investigação que realizara nas terras de Morla-muno. O comandante militar mencionava a existência de um provável acordo entre o cônsul inglês Churchill e Cecil Rhodes, que representava uma associação de várias companhias de exploração de minérios na África oriental. Além disso, mostrava que os ingleses Daniel Grove e Croseford já tinham iniciado as negociações com Morla-muno antes da viagem e que se aproximaram das autoridades portuguesas com o objetivo de impedir a exploração por parte do governo inglês e de Cecil Rhodes. ${ }^{87}$

Este episódio demonstra a dinâmica das relações entre diferentes agentes sociais para além das chefias locais e o governo português. A possibilidade de exploração de minérios na região atraía os interesses econômicos e políticos de representantes de outros governos europeus e de membros de associações de companhias privadas contribuindo para as disputas e negociações locais.

Por outro lado, a ocupação dos territórios e a consequente instituição dos mecanismos coloniais geravam o descontentamento das populações e a oposição dos chefes locais. Em 1902, as autoridades portuguesas deram início à instalação de um posto português em Boila na região da Imbamela. Nessa empreitada, o engenheiro Paes de Almeida e seu sócio e antigo sargento Pita Simões foram assassinados no território de Mogovola pelos guerreiros do chefe Cobula-muno. ${ }^{88}$

Cobula-muno era o chefe principal da Mogovola, a oeste do rio M'luli, e vivia numa povoação fortificada. ${ }^{89}$ Paes de Almeida fora incumbido de promover a instalação do posto de Boila porque conhecia muito bem o território, pois já há algum tempo trabalhava na prospecção de reservas de minérios na região. Além disso, exercia grande influência entre as populações, sobretudo entre os chefes, o que resultava em promessas de que estes aceitariam de bom grado a existência de um posto militar e de lojas comerciais em suas terras. ${ }^{90}$

Entretanto, há indícios de que Paes d'Almeida não objetivava apenas instalar o posto português, mas tinha interesse também no recrutamento de trabalhadores para o Transvaal. De acordo com o governador de Moçambique, Jayme Pimentel, o capitão-mor de Angoche averiguou entre os

\footnotetext{
${ }^{87}$ Correspondência do comandante militar de Angoche ao secretário geral do Governo Geral de Moçambique. Antonio Ennes, 26 de novembro de 1895. AHM, Fundo do século XIX, Governo Geral de Moçambique, 1895, caixa 8-105, maço 3.

${ }_{88}$ AHU, Processos gerais, Moçambique, 1902-1905, caixa 1548, pasta 384, Anexo do documento no 4 .

${ }^{89}$ AMORIM, Pedro Massano de, op. cit., 1911, p. 49-50.

${ }^{90}$ AHU, Processos gerais, Moçambique, ano 1902-1905, caixa 1548, pasta 384. “Cópia a que se refere o Ofício $\mathrm{n}^{\circ} 44^{\prime \prime}$.
} 
rev. hist. (São Paulo), n. 171, p. 383-419, jul.-dez., 2014 http://dx.doi.org/10.11606/issn.2316-9141.rh.2014.89017
Regiane Augusto de Mattos

A dinâmica das relaç̃es no norte de Mocambique no final do século XIX e início do século XX

habitantes de Antonio Enes que o engenheiro Paes d'Almeida desejava ir a Mogovola com o objetivo de reconhecer as terras e as populações que pudessem fornecer gente para imigração.

O governador geral interino Thomas Antonio Faria Rocado demonstrava preocupação com a repercussão do episódio de maneira desfavorável para o governo português. ${ }^{91} \mathrm{~A}$ ameaça dos interesses ingleses na região também contribuiu para que, em maio de 1903, o governo português organizasse uma expedição que arrasou a povoação do chefe de Boila, sendo construída aí uma fortificação guarnecida por oitenta homens. ${ }^{92}$

De acordo com Pedro Massano de Amorim, após a ocupação de Boila, cresceram as ações dos chefes da região, que cobravam tributos dos comerciantes e do comandante militar de Moma "que se submeteu à imposição". Em junho de 1903, o chefe da região de Matadane, Corropa, "saqueava e destruía uma lancha de um negociante que encalhara na praia, em terras suas, respondendo insolentemente aos negociadores que por parte do capitão-mor de Angoche o foram procurar, para conseguir a entrega das fazendas roubadas". Os inhambacos, ${ }^{93}$ como Mussa M'naide, o sultão de Angoche e seu filho assaltavam as caravanas que saíam de Antonio Enes e seguiam em direção ao sul, assim como as "casquinhas" (pequenas embarcações) que partiam para os canais de Boila eram atacadas por outras tripuladas por imbamelas ou "gentes do M'luli". Os cipaios ${ }^{94}$ que levavam a correspondência

\footnotetext{
91 “Todos estes factos avultam agora a necessidade, há muito reconhecida, de tornar effectivo o nosso domínio no districto de Moçambique. As referências desagradáveis que, na imprensa, fez há pouco o aventureiro Grove, a nossa fraqueza e incapacidade, recebidas com indiferença pela opinião pública, serão talvez recordadas agora por fora a evidenciar a necessidade de os desmentir com factos, tanto mais que os assassinatos de Paes d'Almeida e Pitta Simões estão sugerindo receios de que se levantem embaraços a uma das questões mais importantes para o Transvaal - o recrutamento de trabalhadores para as minas - receios a que o cônsul inglês n'esta cidade alude já n'um officio que me dirigiu pedindo-me informações a tal respeito." AHU, Processos gerais, Moçambique, 1902-1905, caixa 1548, pasta 384.

${ }^{2}$ COUTINHO, João de Azevedo, op. cit., p. 35.

${ }^{93}$ Inhambaco era a designação dada aos membros do clã matrilinear do sultanato de Angoche. Ver nota 60.

${ }^{94}$ Cipais, sipaios ou cipaios, do híndi shipahi, é uma designação inicialmente dada aos soldados de origem indiana que formavam as forças militares portuguesas em Moçambique. Entretanto, no século XIX, é possível perceber que essa designação também se referia aos soldados de origem local. RODRIGUES, Maria Eugénia. Cipaios da Índia ou soldados da terra? Dilemas da naturalização do exército português em Moçambique no século XVIII. História: Questões e Debates. Curitiba: Editora UFPR, nº 45, 2006, p. 83
} 
rev. hist. (São Paulo), n. 171, p. 383-419, jul.-dez., 2014 http://dx.doi.org/10.11606/issn.2316-9141.rh.2014.89017
Regiane Augusto de Mattos

A dinâmica das relações no norte de Moçambique no final do século XIX e início do século XX

do governo português para Moma também eram interceptados e as redes telegráficas eram frequentemente cortadas. ${ }^{95}$

Ressalte-se que não apenas os chefes principais das sociedades do norte de Moçambique agiram contra as tentativas de intervenção do governo português. Indivíduos de diferentes camadas sociais também demonstraram descontentamento em relação às medidas portuguesas.

É possível observar igualmente as atitudes de comerciantes e de trabalhadores, tais como soldados, guias e carregadores, cujas ações, embora pudessem ser movidas por interesses pessoais e imediatos, vinculadas a ganhos materiais ou à mudança da própria situação social, coincidiam com a oposição à cobrança de impostos sobre produtos comercializados e do imposto da palhota, o recrutamento militar e o trabalho compulsório.

Os comerciantes, por exemplo, burlavam a proibição e vendiam disfarçadamente armas e munições às chefias locais. Os guias locais sabotavam as ações militares direcionando as autoridades portuguesas para outros territórios de difícil acesso e com parcos recursos naturais, impedindo que se efetivassem os ataques. Os carregadores se recusavam a realizar o seu trabalho gratuitamente ou utilizavam expedientes que dificultavam o sucesso das campanhas militares. ${ }^{96}$ Os soldados (cipaios) que compunham as forças militares portuguesas desertavam, refugiando-se nos territórios de chefes e sultões do norte de Moçambique, passando a compor o conjunto de seus guerreiros. Além das costumeiras deserções, ocorreram alguns episódios de abandono das forças em plena ação militar. ${ }^{97}$

Diversas razões podem ser atribuídas às ações organizadas por soldados, guias e carregadores, tais como as deserções, as fugas, a resistência em atacar

\footnotetext{
95 AMORIM, Pedro Massano, op. cit., p. 26.

${ }^{96}$ Em 1892, Molide Volay de Sancul informara ao comandante militar do Moginquale, Antonio Diniz Ayalla, que pernoitava em suas terras, que naquela ocasião não poderia lhe fornecer carregadores os quais acusavam as autoridades portuguesas de maus tratos argumentando que, quando chegavam aos comandos portugueses, eram presos e apanhavam, além de não receberem nenhum pagamento pelo serviço realizado. Correspondência do comandante militar do Moginquale, Antonio Diniz Ayalla, ao secretário geral do Governo Geral. Moginqual, 1 de novembro de 1892. AHM, Fundo do século XIX, Governo Geral de Moçambique, 1892, caixa 8-151, maço 1.

${ }^{97}$ Segundo o capitão-mor de Mossuril, durante a guerra contra os namarrais, em 1884, após a ordem de ataque do capitão-mor das Terras Firmes a uma povoação em Ampapa, mais de quatrocentos soldados armados "dividiram-se em grupos e assentaram-se debaixo do alvoredo!", obrigando toda a tropa a retornar para o acampamento. Correspondência do capitão-mor de Mossuril ao secretário geral do Governo de Moçambique. Mossuril, 9 de dezembro de 1884. AHM, Fundo do século XIX, Governo Geral de Moçambique, 1884, caixa 8-147, maço 2.
} 
rev. hist. (São Paulo), n. 171, p. 383-419, jul.-dez., 2014 http://dx.doi.org/10.11606/issn.2316-9141.rh.2014.89017
Regiane Augusto de Mattos

A dinâmica das relaç̃ões no norte de Moçambique no final do século XIX e ińício do século XX

determinadas povoações e a incorporação nas forças militares dos chefes que compunham a "coligação". Essas ações estão relacionadas à questão da arregimentação, dos baixos salários e das péssimas condições de sobrevivência dos trabalhadores. O recrutamento de soldados e a composição dos regimentos, por exemplo, era um problema recorrente enfrentado pelas autoridades portuguesas em Moçambique. Ressalte-se que, embora não haja elementos evidentes para concluir que em todos os episódios soldados, guias e carregadores tiveram um comprometimento político com a "coligação de resistência", agiam contra a instituição de mecanismos de exploração da sua força de trabalho.

\section{Considerações finais}

Dessa maneira, no que se refere aos fatores desencadeadores, procurei demonstrar que o principal objetivo das sociedades do norte de Moçambique que constituíram a coligação era a preservação da sua autonomia política ameaçada pelas iniciativas de ocupação territorial e pela instituição dos mecanismos de exploração impostos pelo governo português, como o controle do comércio e da produção de gêneros agrícolas e de extração, a cobrança de impostos e o trabalho compulsório.

Para compreender as formas de mobilização, procurei demonstrar que os participantes da coligação estavam inseridos num complexo de interconexões gerado a partir das múltiplas relações estabelecidas em meio aos espaços políticos, culturais, religiosos e de trocas comerciais que envolviam os estabelecimentos islâmicos da costa, as sociedades do interior e o sultanato de Zanzibar, as ilhas Comores e Madagascar, mas também indianos, portugueses (incluídos aqueles estabelecidos há muito tempo em território africano), ingleses e franceses. Assim, o complexo de interconexões em que estavam envolvidos se pautava por relações marcadas pelo parentesco, pela doação de terra, pela religião islâmica, pelos contatos comerciais. Essas conexões foram acionadas em momentos de crise, facilitaram as ações conjuntas ou individuais contra as interferências do governo português, sobretudo no final do século XIX. 


\section{Referências bibliográficas}

\section{Fontes}

Arquivo Histórico de Moçambique (AHM). Fundo do século XIX: Governo do Distrito de Angoche; Governo do Distrito de Moçambique; Governo Geral de Moçambique.

Arquivo Histórico Ultramarino (AHU). Correspondência dos governadores. Semu, DGU, Moçambique, caixas: 1290 a 1318 e sem n., pastas: 8 a 54, período 18421878. Correspondência dos governadores. Semu, DGU, $1^{\text {a }}$ e $2^{\text {a }}$ Repartição, Moçambique, caixas período: 1320 a 1359 e sem n., pastas: 1 a 20, 1879-1912. Processos gerais, Semu, DGU, Moçambique, período 1890-1912.

AMORIM, Pedro Massano de. Relatório sobre a occupação de Angoche; operações de campanha e mais serviços realizados. [Lourenço Marques]: Imprensa Nacional, 1911.

CASTRO, Soares de. Os Lómuès do Larde. Lourenço Marques: Sociedade de Estudos de Moçambique, 1952.

COUTINHO, João de Azevedo. As duas conquistas de Angoche. Lisboa: Pelo Império, 11, 1935.

GROVE, Daniel. África oriental portuguesa: A Macua. Boletim da Sociedade de Geografia de Lisboa. Lisboa, 1897.

LUPI, Eduardo do Couto. Angoche. Breve memória sobre uma das capitanias-mores do distrito de Moçambique. Lisboa: Typographia do Annuario Commercial, 1907.

NEVES, F. A. da Silva. Informações acerca da capitania-mor de Angoche. Moçambique: Imprensa Nacional, 1901.

O'NEILL, Henry. África oriental portuguesa: Observações acerca da costa e do interior da província de Moçambique. Boletim da Sociedade de Geografia de Lisboa. Lisboa, 1882.

PEIRONE, Federico. Correntes islâmicas moçambicanas. Lisboa: [s.n., D. L. 1964].

VILHENA, Ernesto Jardim de. Cia. do Nyassa. Relatório e memórias sobre os territórios. Lisboa: Typographia da "A Editora", 1906.

\section{Bibliografia}

ABBINK, Jon $\mathcal{E}$ WALRAVEN, Klass van. Repensar la resistencia en la historia de África. In: ABBINK, Jon; BRUIJN, Mirjam; WALRAVEN, Klass van (eds.). A propósito de resistir. Repensar la insurgencia en África. Barcelona: Oozebap, 2008.

ALPERS, E. East Africa and the Indian ocean. Princeton: Markus Wiener, 2009.

ALPERS, E. East central Africa. In: LEVTZION, N. E POUWELS, R. L. (eds.). The history of Islam in Africa. Atenas: Ohio University Press; Oxford: James Curry; Cape Town: David Philip, 2000, p. 303-327.

AMSELLE, Jean-Loup. Branchements. Anthropologie de l'universalité des cultures. Paris: Flammarion, 2001.

BENNET, Normam R. Zanzibar, Portugal e Moçambique: relações dos fins do século XVIII até 1890. Revista Internacional de Estudos Africanos. Lisboa, 6/7, jan.-jun. 1984. 
rev. hist. (São Paulo), n. 171, p. 383-419, jul.-dez., 2014 http://dx.doi.org/10.11606/issn.2316-9141.rh.2014.89017
Regiane Augusto de Mattos

A dinâmica das relações no norte de Moçambique no final do século XIX e início do século XX

BONATE, Liazzat J. K. Matriliny, Islam and gender in northern Mozambique. Journal of Religion in Africa. Leiden: Brill, v. 2, 36, 2006, p. 139-166.

From Shirazi into Monhé: Angoche and the mainland in the context of the nineteenth century slave trade of northern Mozambique. In: ZIMBA, B.; ALPERS, E.; IASAACMAN, A. Slave route and oral tradition in southeastern Africa. Maputo, Moçambique: Filsom Entertainment Ltda., 2005, p. 195-218.

The ascendance of Angoche: politics of kinship and territory in northern Mozambique. In: RESEARCH SEMINAR IN HISTORY. Anais. Universidade de Northwestern, EUA, 2003.

Traditions and transitions: Islam and chiefship in northern Mozambique, ca. 18501974, Tese de doutorado, Departamento de Estudos Históricos, Universidade de Cape Town, África do Sul, 2007.

CAMPBELL, Gwyn. Madagascar and Mozambique in slave trade of the western Indian ocean, 1800-1861. Slavery \& Abolition, nº 9, 1988.

CAPELA, José. Como as aringas de Moçambique se transformaram em quilombos. Tempo. Revista do Departamento de História da UFF. Rio de Janeiro: 7 Letras, v. 10, $\mathrm{n}^{\mathrm{o}} 20$, jan-jun 2006.

A República militar da Maganja da Costa (1862-1898). Maputo: Arquivo Histórico de Moçambique, 1988.

CAPELA, José \& MEDEIROS, Eduardo. O tráfico de escravos nos portos de Moçambique. Porto: Edições Afrontamento, 2002.

CARVALHO, Álvaro Pinto de. Notas para a história das confrarias islâmicas na ilha de Moçambique. Arquivo. Boletim do Arquivo Histórico de Moçambique. Maputo: Arquivo Histórico de Moçambique, 4, outubro de 1988.

CASTRO, Soares de. Os Lómuès do Larde. Lourenço Marques: Sociedade de Estudos de Moçambique, 1952.

CLARENCE-SMITH, William. The economics of the Indian ocean slave trade in the nineteenth century. Londres: Frank Cass, 1989.

COOPER, Frederick. Conflito e conexão: repensando a história colonial da África. Revista Anos 90. Porto Alegre, v. 15, nº 27, jul. 2008.

ELLIS, Steven. La conquista colonial en el centro de Madagascar: Quien resistió a qué? In: ABBINK, Jon; BRUIJN, Mirjam; WALRAVEN, Klass van (eds.). A propósito de resistir. Repensar la insurgencia en África. Barcelona: Oozebap, 2008.

GEFFRAY, C. Nem pai nem mãe. Crítica de parentesco: O caso de Macua. Maputo: Editorial Ndjira/Lisboa: Editorial Caminho, 2000.

HAFKIN, Nancy. Trade, society and politics in northern Mozambique, c. 1753-1913. Ph. D. dissertation, Boston University Graduate School, Boston, 1973.

ISAACMAN, Allen. Cotton is the mother of poverty: peasant resistance to forced cotton production in Mozambique, 1938-1961. International Journal of African Historical Studies, $\mathrm{n}^{\mathrm{O}} 13,1980$.

ISAACMAN, Allen E ISAACMAN, Barbara. A tradição da resistência em Moçambique, o vale do Zambeze, 1850-1921. Porto: Edições Afrontamento, 1976, p. 272-321. 
rev. hist. (São Paulo), n. 171, p. 383-419, jul.-dez., 2014 http://dx.doi.org/10.11606/issn.2316-9141.rh.2014.89017
Regiane Augusto de Mattos

A dinâmica das relações no norte de Moçambique no final do século XIX e início do século XX

Resistance and collaboration in southern and central Africa, c. 18501920. The International Journal of African Historical Studies, vol. 10, $\mathrm{n}^{\circ} 1,1977$.

LE GUENNEC-COPPENS, Françoise \& CAPLAN, Pat. Les Swahili entre Afrique et Arabie. Paris: Ed. Kathala, 1991.

LEVTZION, N. \& POUWELS, R. L. (eds.). The history of Islam in Africa. Atenas: Ohio University Press; Oxford: James Curry; Cape Town: David Philip, 2000.

MACAGNO, Lorenzo. Islã, transe e liminaridade. Revista de Antropologia da USP. São Paulo: USP, 2007, v. 50, $\mathrm{n}^{\circ} 1$.

MACAGNO, Lorenzo. Les nouveaux oulémas. La recomposition des autorités musulmanes au nord du Mozambique. Lusotopie. Leiden: Brill, XIV, 1, maio 2007.

MACHADO, A. J. de Mello. Entre os macuas de Angoche. Lisboa, 1970.

MACHADO, Pedro. Awash in a sea of cloth: Gujarat, Africa, and the western Indian ocean, 1300-1800. In: RIELLO, Giorgio E PARTHASARATHI, Prasannan. Spinning world. A global history of cotton textiles, 1200-1850. Nova York: Oxford University Press, 2009, p. 162.

MARTINS, Luísa F. G. Os namarrais do antigo distrito de Moçambqiue: percursos identitários e resistências (1857-1913). Tese de doutorado, Universidade de Évora, 2010.

A expedição militar portuguesa ao Infusse em 1880. Um exemplo de ocupação colonial nas terras islamizadas do norte de Moçambique. In: REUNIÂO INTERNACIONAL DE HISTÓRIA DE ÁFRICA: RELAÇÃO EUROPA-ÁFRICA NO $3^{\circ}$ QUARTEL DO SÉCULO XIX. Anais. Lisboa: Centro de Estudos de História e Cartografia Antiga, Instituto de Investigação Científica e Tropical, 1989.

MATTOS, Regiane Augusto de. As dimensões da resistência em Angoche: da expansão política do sultanato à política colonialista portuguesa no norte de Moçambique (1842-1910). Tese de doutorado em História Social, Faculdade de Filosofia, Letras e Ciências Humanas, Universidade de São Paulo. São Paulo, 2012.

. Islã e resistência: o sultanato de Angoche contra as tentativas de dominação portuguesa no norte de Moçambique. In: RIBEIRO, Alexandre Vieira E GEBARA, Alexsander Lemos de Almeida. (org.). Estudos africanos: múltiplas abordagens. Niterói: Editora da UFF, 2013, p. 98-119.

MBWILIZA, Joseph F. A history of commodity production in Makuani, 1600-1900. Dar es Salaam: Dar es Salaam University Press, 1991.

MEDEIROS, Eduardo. Irmandades muçulmanas no norte de Moçambique. In: ANGIUS, Matteo \& ZAMPONI, Mario. Ilha de Moçambique: convergência de povos e culturas. AIEP editora, 1989.

O Islão e a construção do espaço cultural e social Macua. In: RODRIGUES, José Damião \& RODRIGUES, Casimiro. Representações de África e dos africanos na história e cultura - séculos XV a XXI. Lisboa: Centro de História de Além-Mar, 2011, p. 195-280.

As etapas da escravatura no norte de Moçambique. Maputo: Arquivo Histórico de Moçambique, 1988.

NEWITT, Malyn. Angoche, the slave trade and the Portuguese. The Journal of African History, v. 13, no 4, 1972, p. 659-672. 
rev. hist. (São Paulo), n. 171, p. 383-419, jul.-dez., 2014 http://dx.doi.org/10.11606/issn.2316-9141.rh.2014.89017
Regiane Augusto de Mattos

A dinâmica das relações no norte de Moçambique no final do século XIX e início do século XX

The early history of the sultanate of Angoche. The Journal of African History, v. 13, nº 3, 1972, p. 397-406.

NIMTZ JR., A. Islam and politics in east Africa: the Sufi ordes in Tanzania. Minneapolis: Minnesota University Press, 1980.

POUWELS, R. L. Horn and crescent: cultural change and traditional Islam in east African coast, 800-1900. Cambridge: Cambridge University Press, 1987.

PEARSON, M. N. Port cities and intruders: the Swahili coast, India, and Portugal in the early Modern era. Baltimore: The Johns Hopkins University Press, 1998.

PEIRONE, Federico. Correntes islâmicas moçambicanas. Lisboa: [s.n., D. L. 1964].

PÉLISSIER, René. História de Moçambique. Formação e oposição (1854 - 1918). Lisboa: Editorial Estampa, v. 1, 1987.

PENRAD, Jean-Claude. Commerce et religion: expansion et configurations de l'Islam en Afrique oriental. In : O ISLÃO NA ÁFRICA SUBSAARIANA: $6^{\circ} \mathrm{CO}-$ LÓQUIO INTERNACIONAL. ESTADOS, PODERES E IDENTIDADES NA ÁFRICA SUBSAARIANA. Actas. Porto: Univ. do Porto, Centro de Estudos Africanos, 2004.

RANGER, Terence O. Connexions between primary resistance movements and modern mass nationalism in east and central África. The Journal of African History. Cambridge University Press, IX, 3, 1968, p. 437-453.

RANGER, Terencer O. Iniciativas e resistência africanas em face da partilha e da conquista. In: BOAHEN, A. Adu. (coord.). História geral da África. A África sob dominação colonial, 1880-1935, v. 7. Ática/Unesco, 1985.

RITA-FERREIRA, Antonio. Fixação portuguesa e história pré-colonial de Moçambique. Lisboa: Instituto de Investigação Científica Tropical/Junta de Investigações Científicas do Ultramar, 1982.

ROCHA, Aurélio. O caso dos suaílis, 1850-1913. In: REUNIÃO INTERNACIONAL DE HISTÓRIA DE ÁFRICA: RELAÇÃO EUROPA-ÁFRICA NO $3^{\circ}$ QUARTEL DO SÉCULO XIX. Anais. Lisboa: Centro de Estudos de História e Cartografia Antiga, Instituto de Investigação Científica e Tropical, 1989.

SHERIFF, Abdul. Slaves, spices and ivory in Zanzibar: integration of an East African commercial empire into the world economy, 1770-1873. Londres: James Curvery, 1987.

SCOTT, James. Weapons of the weak: everyday forms of peasant resistance. New Haven: Yale University Press, 1985.

TRIMINGHAM, J. S. Islam in East Africa. Oxford: Clarendon Press, 1964.

ZAMPARONI, Valdemir. Monhés, baneanes, chinas e afro-maometanos. Colonialismo e racismo em Lourenço Marques, Moçambique, 1890-1940. Lusotopie. Paris: Ed. Karthala, 2000. 
rev. hist. (São Paulo), n. 171, p. 383-419, jul.-dez., 2014 http://dx.doi.org/10.11606/issn.2316-9141.rh.2014.89017
Regiane Augusto de Mattos

A dinâmica das relaçōes no norte de Moçambique no final do século XIX e início do século XX

\section{PRINCIPAIS ÁREAS COMERCIAIS DO OCEANO ÍNDICO}

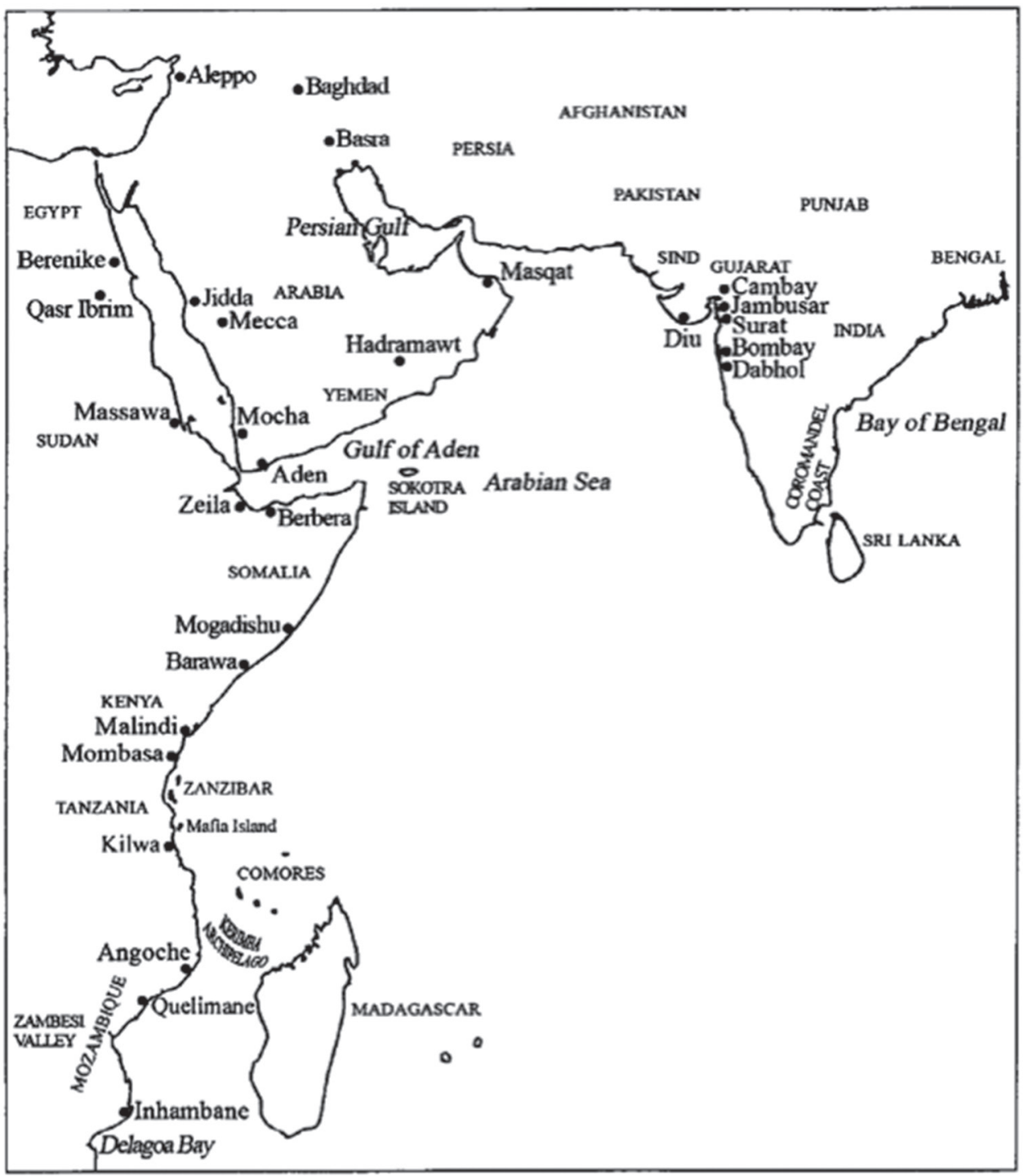

Map 8.1. Areas of cotton textile trade in the western part of the Indian Ocean

Fonte: MACHADO, Pedro. Awash in a sea of cloth: Gujarat, Africa, and the western Indian ocean, 1300-1800. In: RIELLO, Giorgio \& PARTHASARATHI, Prasannan. Spinning world. A global history of cotton textiles, 1200-1850. Nova York: Oxford University Press, 2009, p. 162. 
rev. hist. (São Paulo), n. 171, p. 383-419, jul.-dez., 2014 http://dx.doi.org/10.11606/issn.2316-9141.rh.2014.89017
Regiane Augusto de Mattos

A dinâmica das relaç̃oes no norte de Moçambique no final do século XIX e início do século XX

\section{“ESBOÇO GEOGRÁFICO DE ANGOCHE, 1903"}

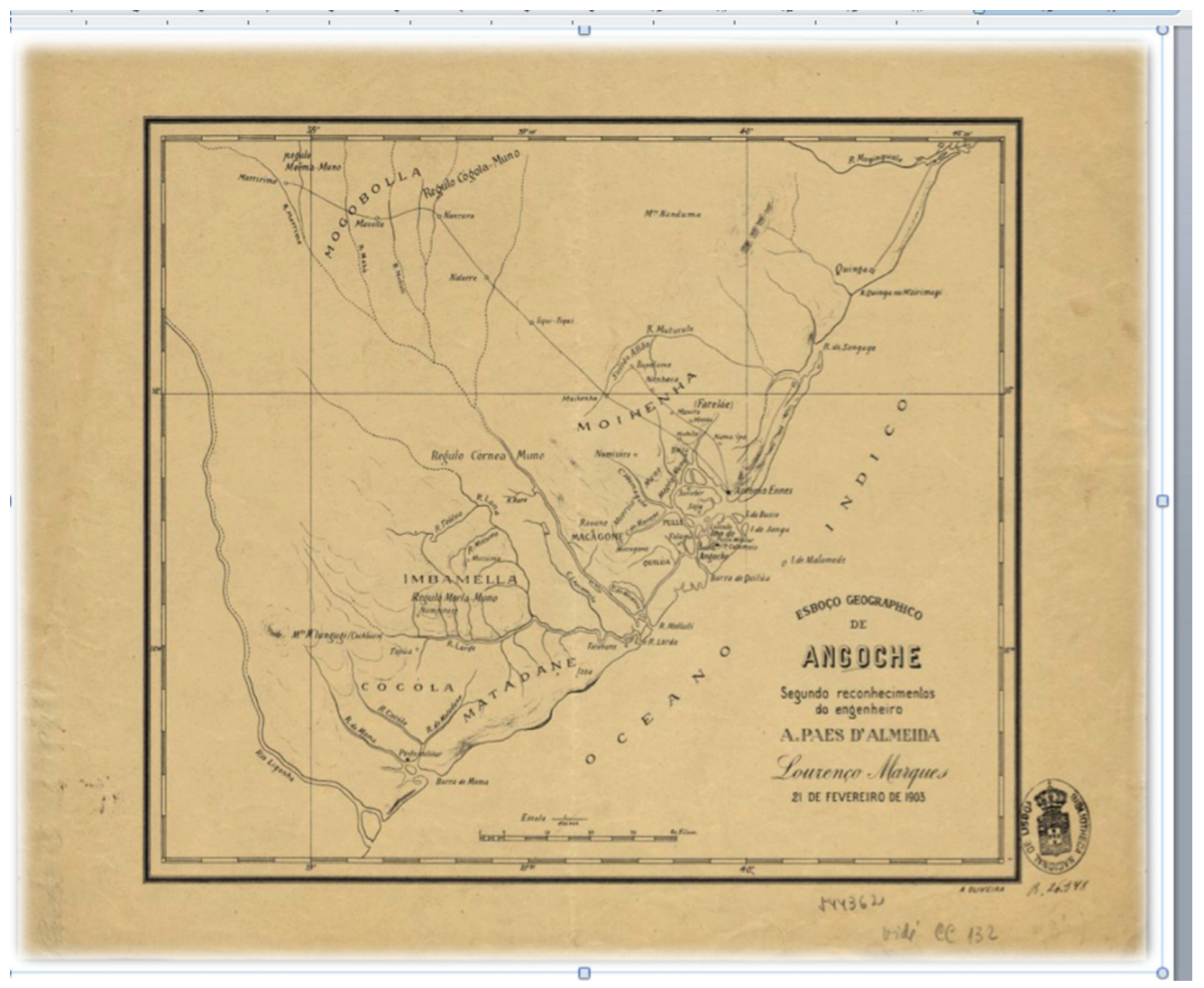

Fonte: PAES D'ALMEIDA, A. Esboço geográfico de Angoche. Lourenço Marques: Biblioteca Nacional de Portugal, 1903.

Recebido 05/05/2014 - Aprovado: 21/10/2014. 